\title{
COMPARISON OF THE HYDROGEOCHEMICAL AND MECHANICAL BEHAVIOURS OF COMPACTED BENTONITE USING DIFFERENT CONCEPTUAL APPROACHES
}

Yustres, A. a, ${ }^{*}$, Jenni, A. ${ }^{\mathrm{b}}$, Asensio, L. ${ }^{\mathrm{a}}$, Pintado, X. ${ }^{\mathrm{c}}$, Koskinen, K. ${ }^{\mathrm{d}}$, Navarro, V. ${ }^{\mathrm{a}}$, Wersin, P. ${ }^{\mathrm{e}}$

${ }^{a}$ Geoenvironmental Group, Civil Engineering Department, University of Castilla-La Mancha, Avda. Camilo José Cela s/n, 13071 Ciudad Real, Spain

${ }^{\mathrm{b}}$ RWI, Institute of Geological Sciences, University of Bern, 3012 Bern, Switzerland

${ }^{\mathrm{c}}$ B + Tech Oy, Laulukuja 4, 00420 Helsinki, Finland

${ }^{\mathrm{d}}$ Posiva Oy, Olkiluoto, 27160 Eurajoki, Finland

${ }^{\mathrm{e}}$ University of Bern, Institute of Geological Sciences, Baltzerstrasse 1+3, 3012 Bern, Switzerland

* Corresponding author: angel.yustres@uclm.es , Civil Engineering School, University of Castilla-La Mancha, Avda. Camilo José Cela s/n, 13071 Ciudad Real, Spain

A. Yustres, A. Jenni, L. Asensio, X. Pintado, K. Koskinen, V. Navarro, P. Wersin, Comparison of the hydrogeochemical and mechanical behaviours of compacted bentonite using different conceptual approaches, Applied Clay Science, Volume 141, 1 June 2017, Pages 280-291, ISSN 0169-1317, http://dx.doi.org/10.1016/j.clay.2017.03.006. 


\section{HIGHLIGHTS}

- Two hydro-chemo-mechanical models for compacted bentonite are compared.

- A good agreement between models in the swelling pressure can be observed.

- Concentrations in the macroporosity are similar in both models.

- The role of the microporosity and its evolution over time is stressed.

\section{GRAPHICAL ABSTRACT}

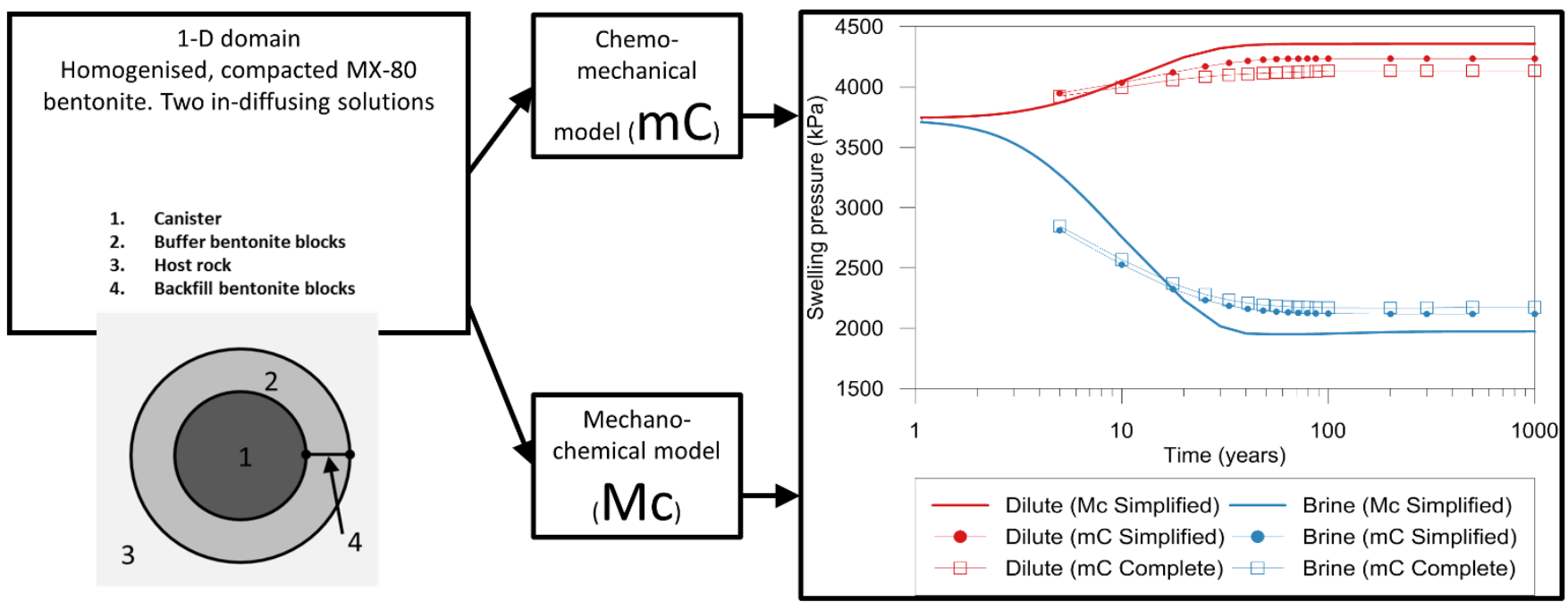




\begin{abstract}
This study compares the capabilities of two numerical models that simulate the behaviour of compacted saturated MX-80 bentonite exposed to different chemical environments. Both codes have different approaches: one of them is a reactive transport model, and the other is a hydrogeomechanical model. The study shows that the combined use of both approaches provides a useful basis for designing bentonite barriers in the geological disposal of high-level nuclear waste. Although, their application is now limited to simple geometries and boundary conditions, the proposed approaches are a first step towards a fully thermo-hydro-mechano-chemical model. It is also shown that there is a need for a greater understanding of the chemomechanical coupling that occurs at the microstructural scale to achieve this comprehensive model in the future.
\end{abstract}

\title{
KEYWORDS:
}

Hydro-chemo-mechanical modelling, compacted bentonite, swelling pressure, engineered barriers, MX-80 bentonite 


\section{INTRODUCTION}

Bentonite is the most promising candidate buffer and backfill material for in engineered barrier systems in subsurface repositories of high-level nuclear waste. The current design in Sweden and Finland is called KBS-3 and has two alternatives, KBS-3V (SKB, 2010; Posiva Oy, 2012) and KBS-3H (Posiva Oy, 2013), both using bentonite as barrier. This natural material has favourable properties such as its swelling capacity, its low permeability at full saturation, and its capacity to passivate or retard certain geochemical processes (Arthur and Zhou, 2000; Arthur et al., 2005). Consequently, there is an objective need for understanding the complex behaviour of this material in the short, medium and long term (SKB, 2010). For example, the swelling pressure developed by a bentonite buffer is an important design consideration (SKB, 2010; Posiva Oy, 2012). According to safety requirements, swelling pressures should lie within a range of 2-15 MPa (Posiva Oy, 2012). Values higher than this may damage the canister and therefore significantly affect the safety of the repository. Variations in the swelling pressure may be due to multiple factors (Raiko et al., 2010), including the geometry and arrangement of the buffer with respect to the fractures of the host rock, the mineralogy of the bentonite, the type of predominant counterions (e.g., $\mathrm{Na}^{+}, \mathrm{Ca}^{2+}, \mathrm{Mg}^{2+}$ ), or the chemical composition of the surrounding groundwaters. It has been verified experimentally that the chemistry of the saturating water affects the permeability (Dixon, 2000; Cho et al., 2002; Karnland et al., 2006; Castellanos et al., 2008; Zhu et al., 2013), the strength properties (Di Maio and Fenelli, 1994; Börgesson et al., 1995; Di Maio, 1996; Jeong et al., 2012; Sinnathamby et al., 2015), the deformational properties (Bolt, 1956; Mesri and Olson, 1971; Sridharan and Rao, 1973; Low, 1980; Di Maio et al., 2004; Calvello et al., 2005; Castellanos et al., 2006; Ye et al., 2014; Zhu et al., 2015; Chen et al., 2016) or the mineralogical composition due to processes such as illitization (Hökmark et al., 1997; Wersin et al., 2007) or 
chloritization, among other processes (Karnland and Birgersson, 2006; Gómez-Espina and Villar, 2010; Marty et al., 2010; Xiaodong et al., 2011; Gómez-Espina and Villar, 2015). However, the swelling pressure under different salinity conditions and types of solutes has traditionally been the most experimentally studied variable (Low, 1980; Pusch, 1980; Dixon et al., 1996; Karnland, 1998; Dixon, 2000; Karnland et al., 2006). In all cases, an increase in the ionic strength of the saturating fluid translates into a reduction of the swelling pressure (Savage, 2005). Consequently, it is essential to understand the long-term chemical composition of the surrounding groundwaters of a repository. However, even though a detailed experimental characterization of the material (Herbert et al., 2004; Karnland et al., 2005; Karnland et al., 2006; Yamaguchi et al., 2007; Herbert et al., 2008) and its behaviour with different pore water compositions has already been performed, the slowness of the processes, which is associated with the system's low saturated hydraulic conductivity, does not allow for real-scale experimentation in many cases. This type of in situ testing has only been performed in a few studies (Karnland et al., 2000; Alonso et al., 2005; Pacovský et al., 2007; Svoboda, 2007; Li et al., 2013; Martín et al., 2014; Liu et al., 2016) with long test times, high costs, and variable degrees of interpretation and understanding.

In this context, the numerical modelling of the multiphysics processes that occur in bentonite is important. Historically, in a first approach, mechanical processes were coupled with hydraulic (i.e., HM models) (Alonso et al., 1990; Gens and Alonso, 1992; Börgesson et al., 1996) and thermal processes (i.e., THM models) (Olivella et al., 1996; Thomas and He, 1997; Navarro and Alonso, 2000). It is less common to find multicomponent geochemical transport models in conjunction with those previously cited (i.e., THMC models) because the coupling of all these phenomena is complicated (Guimarães et al., 2013; Lei et al., 2014; Sedighi et al., 2015). Additionally, there is no 
single conceptual model that combines all of these processes effectively and accurately. Thus, different approaches have been used to reduce the complexity of the chemomechanical coupling, either by reducing the amount of chemical species and reactions involved in the geochemical model or by simplifying the mechanical constitutive model. This study evaluates the ability of two models, each of which uses one of the aforementioned simplifications, to estimate the evolution of different variables, both chemical and mechanical, and also evaluates their capability to be used in a complementary manner in the design of engineered barrier systems for spent nuclear fuel and other nuclear wastes. Furthermore, this study is a first step before a complete conceptual and numerical thermo-hydro-mechano-chemical model, for which a better understanding of the phenomena involved is still needed.

\section{DESCRIPTION OF THE MODELS}

The first of the numerical models considered in this study is the CRUNCHFLOW model (Steefel et al., 2015), which is a geochemical transport model with a simplified auxiliary geomechanical model implemented in the CRUNCHFLOWMC version; this model is referred to as the $\mathrm{mC}$ model in this study. The second model, developed in a Comsol Multiphysics environment, was proposed by Navarro et al. (2017), which is primarily mechanical with a simplified geochemical model; this model is referred to as the Mc model in this study. Both models use a double-porosity approach to describe the compacted bentonite system. In this study, macroporosity is defined as the aggregate pore space, and microporosity is defined as the intra aggregate pore space (Romero et al., 2011). Both models also define chemical equilibrium between ions in the two porosity domains using the Donnan equilibrium approach (Tournassat and Appelo, 2011; AltEpping et al., 2015). The Donnan equilibrium substitutes cation exchange: the total 
positive charge in the microporosity, balancing the negative charge of the clay mineral layer, represents the cation exchange capacity of the bentonite. The composition in the microporosity reflects the exchangeable cation occupancy. The Donnan pore space in both models is considered to be the total microporosity; the presence of a Stern layer containing immobile cations near the negatively charged montmorillonite sheet surface is not explicitly considered. Any montmorillonite edge site reactions have been discarded; no significant $\mathrm{pH}$ changes are expected in this numerical experiment. Therefore, the potential buffer role that edge sites can play via protonation or deprotonation will not be relevant in this comparison. The ability to simulate the flow of the liquid phase in unsaturated conditions is also a common feature in the two models, although only problems full saturation will be analysed in this study. Finally, solute transport occurs in both microporosity (diffusive only) and in macroporosity (both advective and diffusive). Diffusion coefficients can be set individually for micro- and macroporosity.

Despite the common conceptual structures, ionic distribution and solute transport methods of the models, there are important differences in the modelling approaches with regard to geochemical modelling. The $\mathrm{mC}$ model is a multicomponent reactive transport code including thermodynamic equilibria, kinetic mineral precipitation/dissolution reactions, surface complexation, and conventional ion exchange (Alt-Epping et al., 2015; Steefel et al., 2015). On the other hand, the geochemical system of the Mc model is limited because it only considers one anion $(\mathrm{Cl})$ and two cations $\left(\mathrm{Na}^{+}\right.$and $\left.\mathrm{Ca}^{2+}\right)$ and does not consider any reactions between them. Although this chemical system can reproduce behaviour trends that have been observed in various tests in the literature (Karnland et al., 2006; Castellanos et al., 2008; Ye et al., 2015), the chemical phenomena that alter the original mineralogy of bentonite (Karnland and Birgersson, 2006) cannot be simulated by these models. 
In terms of geomechanical modelling, the levels of sophistication of both codes are opposite. In the Mc model, a complete elastoplastic constitutive model (Navarro et al., 2013, 2014) was chosen based on the Barcelona Expansive Model (BExM) (Alonso et al., 1999; Sánchez et al., 2005), although it includes differentiating elements. First, the model Mc includes a formulation of the water exchange kinetics between micro- and macroporosities that considers the chemical potential difference between both porosity levels (Navarro et al., 2016). The model also uses a constitutive model of the behaviour of the microstructure that is based on the interpretation of retention curves at high suction values (Navarro et al., 2015) and incorporates an alternative definition of the interaction function between the micro- and macrostructural strains to consider the free swelling phenomena and the effect of the salinity of the saturating water (Navarro et al., 2017). The result is a model that includes the major parameters controlling the hydromechanical behaviour of the bentonite.

In the $\mathrm{mC}$ model, the microporosity volume is calculated from the Debye length, which is inversely proportional to the square root of ionic strength in the macroporosity (Tournassat and Appelo, 2011). Because the Debye length overlaps in compacted bentonites, the interlayer thickness is a fraction of Debye length, and this parameter (termed multiplier) is considered as constant for fixed bentonite dry density. Microporosity volume can then be derived by multiplying interlayer thickness with the total specific surface area of montmorillonite. Macroporosity follows from the total volume constraint and the known dry density. The Debye length multiplier is derived from experimental data stating interlayer distances in MX80 bentonite at different dry densities and known macroporosity ionic strength (Holmboe et al., 2012). The final expression for the calculation of the microporosity $\left(n_{\mathrm{m}}\right)$ is 
$n_{\mathrm{m}}=S S A \cdot \lambda \cdot \frac{\beta}{\sqrt{I}}$

Eq. 1

where SSA is the total specific surface area of montmorillonite, $\beta$ is a time-dependent physical constant $\left(3.03743 \times 10^{-10} \mathrm{~m}\right.$, Tournassat and Appelo, 2011), $\lambda$ is the multiplier. Moreover, there is no geomechanical module to solve the mechanical equilibrium equation. An empirical correlation proposed by the authors is used to apply experimental data found in the literature (Karnland et al., 2006). The expression

$P_{\text {swell }}=2 \cdot b \cdot \operatorname{arcoth}(a \cdot I+d)+c$

links ionic strength $\mathrm{I}(\mathrm{M})$ and swelling pressure $\mathrm{P}_{\text {swell }}(\mathrm{kPa})$, the parameters in Table 1 result in satisfactory fits of the experimental data for both sodium- and calciumdominated bentonites (Figure 1) for a montmorillonite dry density of $1380 \mathrm{~kg} / \mathrm{m}^{3}$. Equation 2 is used for swelling pressure estimation, assuming that ionic strength $(I)$ in the macroporosity and dry density (via the parameters $a, b, c$ and $d$ ) are the only governing parameters. A possible response of the Debye length multiplier on swelling pressure is neglected and the multiplier is kept constant. A further evaluation of the experimental data conducted at different ionic strengths from (Karnland et al., 2006), reveals that swelling pressures at $480 \mathrm{~kg} / \mathrm{m}^{3}$ dry density are higher for Na-montmorillonite than for Ca-montmorillonite. Surprisingly, swelling pressures at $780 \mathrm{~kg} / \mathrm{m}^{3}$ are higher for Camontmorillonite above approx. 2.5 M. This turning point moves further down in ionic strength with increasing dry density. At $1690 \mathrm{~kg} / \mathrm{m}^{3}$, Ca-montmorillonite shows higher swelling pressures over the entire ionic strength range investigated. A conclusive explanation for this behaviour is missing, as well as coherent data on mixed $\mathrm{Ca}-\mathrm{Na}$ (or additional cation) systems. However, literature data (Birgersson et al., 2009) suggests swelling pressures of $\mathrm{Ca}-\mathrm{Na}$ bentonite similar to pure $\mathrm{Na}$ bentonite up to $80 \% \mathrm{Ca}$ 
occupancy, which is above Ca occupancies considered in this study. Therefore, mixed $\mathrm{Na}-\mathrm{Ca}$ bentonites are mechanically treated as $\mathrm{Na}$ bentonites.

\begin{tabular}{crr} 
Parameter & Na-montmorillonite & Ca-montmorillonite \\
\hline $\mathbf{a}$ & 111.8 & 24.8 \\
$\mathbf{b}$ & 510672.4 & 600913.8 \\
$\mathbf{c}$ & -460.1 & -1613.4 \\
$\mathbf{d}$ & 215.2 & 257.8 \\
\hline
\end{tabular}

Table 1. Parameters from fitting Equation 2 to measured data (Figure 1).

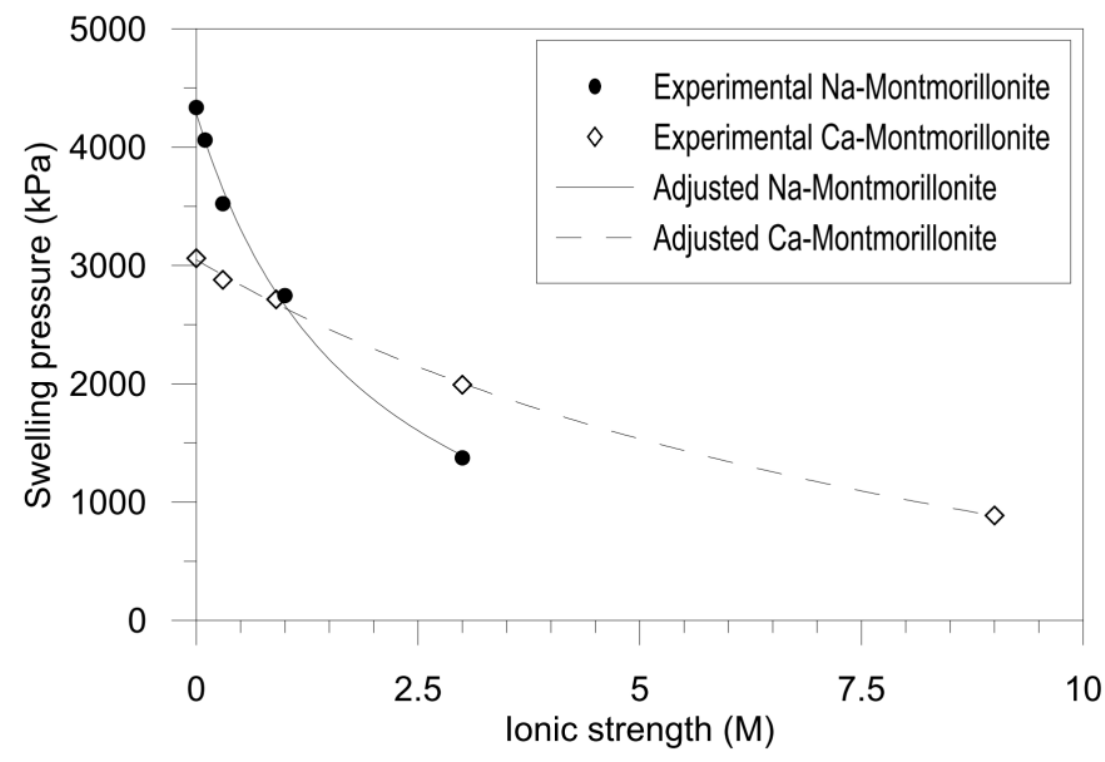

Figure 1. Swelling pressures at different ionic strength deduced from measurements (dots, Karnland, Olsson, and Nilsson 2006), and fitted curves after equation 2 with parameters from Table 1. Montmorillonite dry density is $1380 \mathrm{~kg} / \mathrm{m} 3$.

\section{PROPOSED INTERCOMPARISON EXERCISE}

In the previous section, it is pointed out that none of the conceptual models behind these numerical codes take into account all the processes that occur in bentonite. This study addresses the question whether both codes can make long term and consistent estimates 
of different variables of interest in such a way that they may be used in a complementary manner in design studies of engineered barrier systems.

A simplified comparison was proposed such that it is not outside the range of application of any of the two models. The behaviour of the engineered barrier is analysed around the canister containing spent nuclear fuel located in a vertical deposition hole (Figure 2a). To accomplish this, a radius (see Figure $2 \mathrm{~b}$ ) of the bentonite buffer is modelled as a 1D domain. In reality, the system is an axisymmetric problem. Both models will produce the same inaccuracies due to this geometric simplification, and consequently, the code comparison will be consistent. The size of the simulated element is $0.35 \mathrm{~m}$, the thickness of the bentonite buffer after emplacement in partially saturated state and subsequent full saturation and homogenisation. Saline groundwater, whose composition has been used as a reference in the safety assessments for KBS-3H and KBS-3V (Nykyri et al., 2008; Smith et al., 2008), has been considered to be the saturating water in this study (see Table 2). These conditions are assumed to be representative of the baseline conditions at the Olkiluoto site foreseen to host a spent fuel repository. The pore fluid composition was obtained after equilibration in the CRUNCHFLOW model of such water with the original mineralogy (Kiviranta and Kumpulainen, 2011) proposed as a buffer material for the benchmark (see Table 3). Using the mean of samples 1-1-Sa and 1-2-Sa (Wyoming MX80), the gypsum content was calculated using the corresponding sulphate content and by assuming all sulphate is present in the form of gypsum. This calculation was based on the values shown in Table 3, which originated from XRD measurements at 54\% relative humidity, where the water content of bentonite was approximately $12 \%$ of the dry mass. Assuming that all water is located in the interlayers of smectite, the corresponding amount of water is subtracted from the smectite content, and the resulting values are upscaled to $100 \%$ by mass and shown in Table 4. 


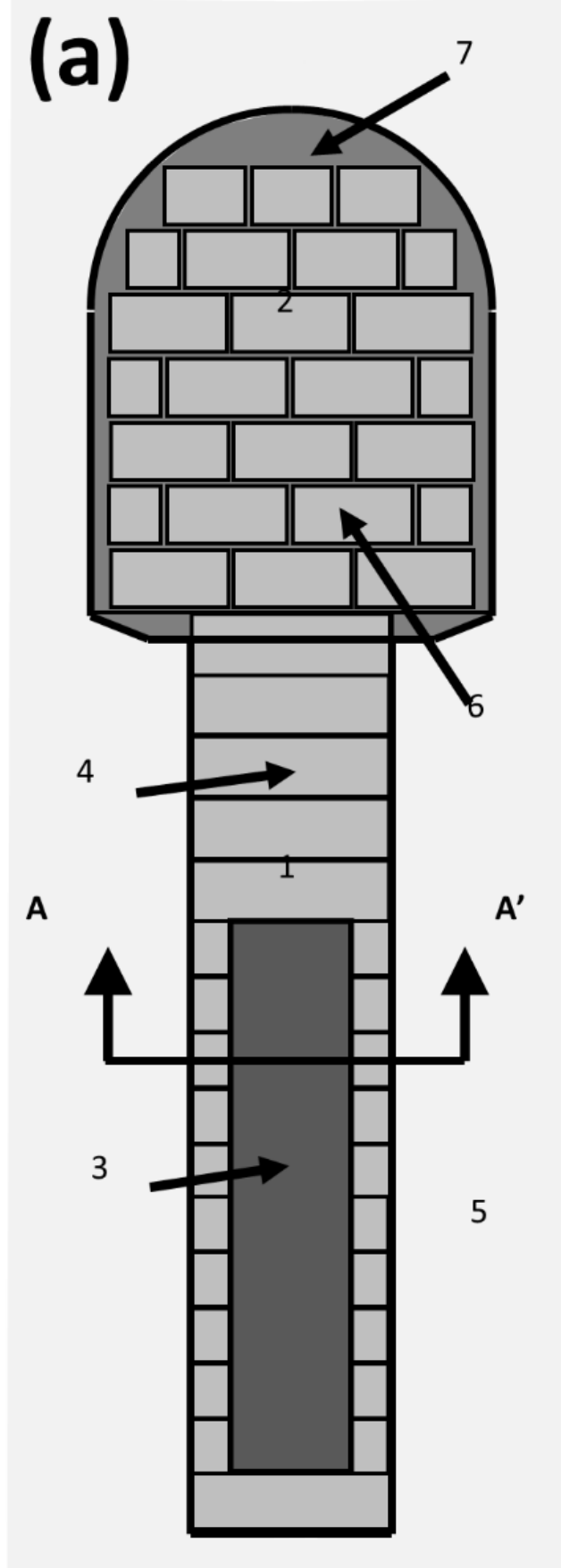

1. Deposition hole

2. Disposal tunnel

3. Canister

4. Buffer bentonite blocks

5. Host rock

6. Backfill bentonite blocks

7. Backfill pellets

8. Simulated domain

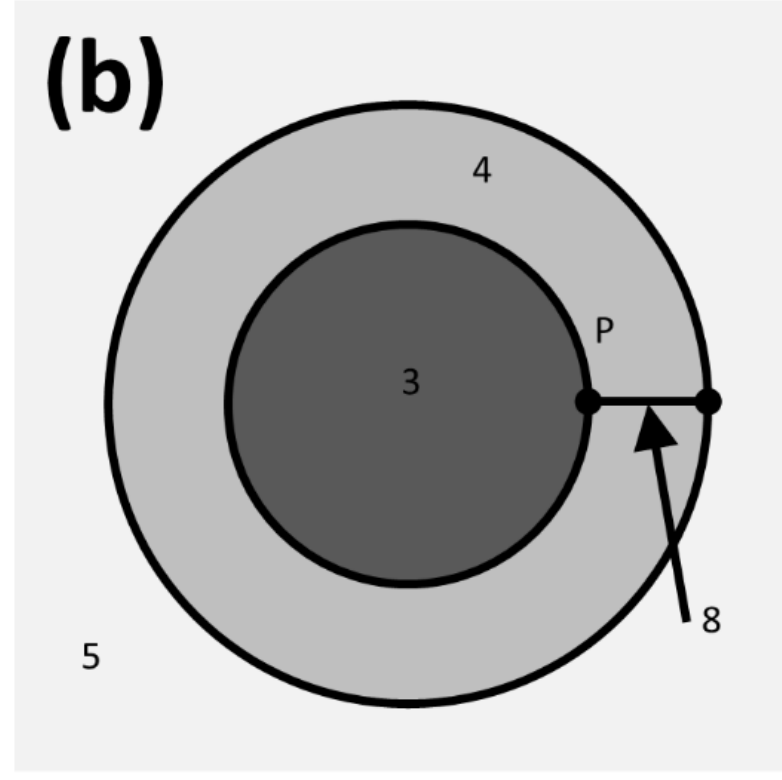

$A-A^{\prime}$ section

Figure 2. (a) Diagram of a vertical deposition hole and an engineered barrier system (b) 1D domain scheme of the proposed comparison. 


\begin{tabular}{|c|c|c|c|}
\hline $\begin{array}{l}\text { Groundwater } \\
\text { type }\end{array}$ & $\begin{array}{l}\text { Dilute carbonate- } \\
\text { rich water }\end{array}$ & Saline water & Brine water \\
\hline Sample & OL-KR4_81_1 & OL-KR20-465-1 & OL-KR4_861_1 \\
\hline $\operatorname{Depth}(z, \mathbf{m})$ & -69 & -360 & -818 \\
\hline $\operatorname{TDS}\left(\mathrm{kg} / \mathrm{m}^{3}\right)$ & 1.1 & 11 & 69 \\
\hline CB $(\%)$ & 3.76 & 0.97 & 0.15 \\
\hline pH & 7.8 & 7.4 & 7.8 \\
\hline Alk. $\left(\mathrm{HCO}_{3}\right)$ & 4.573 & 0.657 & 0.200 \\
\hline DIC (kg/m³) & $58.5 \times 10^{-3}$ & $6.6 \times 10^{-3}$ & $1.0 \times 10^{-3}$ \\
\hline $\mathrm{SO}_{4}$ & 0.958 & 0.208 & $<0.010$ \\
\hline Cl & 9.900 & 180.521 & 1212.873 \\
\hline $\mathbf{N a}$ & 13.136 & 114.834 & 424.102 \\
\hline $\mathbf{K}$ & 0.248 & 0.281 & 0.563 \\
\hline $\mathbf{C a}$ & 1.347 & 32.437 & 391.736 \\
\hline Mg & 0.741 & 2.551 & 4.526 \\
\hline $\mathbf{S r}$ & $5.706 \times 10^{-3}$ & 0.160 & 1.837 \\
\hline $\mathrm{SiO}_{2}$ & 0.200 & 0.166 & $88.209 \times 10^{-3}$ \\
\hline Mn & $3.458 \times 10^{-3}$ & $5.825 \times 10^{-3}$ & $40.045 \times 10^{-3}$ \\
\hline $\mathbf{F e}$ & $8.058 \times 10^{-3}$ & $2.328 \times 10^{-3}$ & $35.813 \times 10^{-3}$ \\
\hline$S^{2-}$ tot & $0.312 \times 10^{-3}$ & $5.614 \times 10^{-3}$ & $<15.6 \times 10^{-3}$ \\
\hline $\mathbf{F}$ & $31.582 \times 10^{-3}$ & $52.636 \times 10^{-3}$ & $84.218 \times 10^{-3}$ \\
\hline $\mathbf{B r}$ & $17.521 \times 10^{-3}$ & 0.551 & 4.355 \\
\hline $\mathrm{NH}_{4}$ & $41.578 \times 10^{-3}$ & $<1.2 \times 10^{-3}$ & $1.663 \times 10^{-3}$ \\
\hline $\mathrm{PO}_{4}$ & $1.685 \times 10^{-3}$ & $<0.32 \times 10^{-3}$ & $0.421 \times 10^{-3}$ \\
\hline B & $26.825 \times 10^{-3}$ & 0.120 & $83.249 \times 10^{-3}$ \\
\hline $\mathrm{N}_{2}$ (gas) & 1.852 & 3.257 & 8.343 \\
\hline $\mathrm{H}_{2}$ (gas) & $0.112 \times 10^{-3}$ & $<0.3 \times 10^{-3}$ & $10.395 \times 10^{-3}$ \\
\hline He (gas) & $0.892 \times 10^{-3}$ & 0.321 & 0.924 \\
\hline $\mathrm{CH}_{4}$ (gas) & $31.677 \times 10^{-3}$ & 6.112 & 41.403 \\
\hline Eh $(\mathbf{m V})$ & -290 & -70 & -60 \\
\hline
\end{tabular}

Table 2. Compositions of the reference waters. 


\begin{tabular}{|c|c|c|c|}
\hline Mineral & $\begin{array}{c}1-1-S a \\
\text { (\% mass) }\end{array}$ & $\begin{array}{c}1-2-\mathrm{Sa} \\
(\% \text { mass }) \\
\end{array}$ & $\begin{array}{r}\text { Mean } \pm \text { Std } \\
(\% \text { mass })\end{array}$ \\
\hline Smectite & 88.5 & 86.7 & $87.6 \pm 1.3$ \\
\hline Illite & 0.1 & 0.1 & $0.1 \pm 0$ \\
\hline Quartz & 4.0 & 4.3 & $4.1 \pm 0.2$ \\
\hline Cristobalite & $\operatorname{tr} ?$ & $\operatorname{tr} ?$ & tr? \\
\hline Plagioclase & 4.2 & 4.2 & $4.2 \pm 0$ \\
\hline Calcite & 0.5 & 0.6 & $0.6 \pm 0.1$ \\
\hline \multicolumn{4}{|l|}{ Dolomite } \\
\hline K-feldspar & 1.5 & 2.1 & $1.8 \pm 0.5$ \\
\hline Biotite & $\operatorname{tr}$ & $\operatorname{tr}$ & $\operatorname{tr}$ \\
\hline \multicolumn{4}{|l|}{ Chlorite } \\
\hline \multicolumn{4}{|l|}{ Hornblende } \\
\hline Zircon & $\operatorname{tr}$ & $\operatorname{tr}$ & $\operatorname{tr}$ \\
\hline Apatite & & $\operatorname{tr}$ & $\operatorname{tr}$ \\
\hline Hematite & 0.1 & $\operatorname{tr}$ & $\operatorname{tr}$ \\
\hline \multicolumn{4}{|l|}{ Goethite } \\
\hline Pyrite & 0.4 & 0.8 & $0.6 \pm 0.3$ \\
\hline Magnetite & $\operatorname{tr}$ & $\operatorname{tr}$ & $\operatorname{tr}$ \\
\hline \multicolumn{4}{|l|}{ Opal-A } \\
\hline Rutile & 0.7 & 1.0 & $0.9 \pm 0.2$ \\
\hline Gypsum & & & \\
\hline
\end{tabular}

Table 3. Mineralogical composition of the MX-80 reference bentonite.

\begin{tabular}{lr} 
Mineral & (mass \%) \\
\hline Smectite dry & 78.50 \\
Gypsum & 0.65 \\
Calcite & 0.55 \\
Illite & 0.10 \\
Quartz & 4.16 \\
Plagioclase & 4.21 \\
Dolomite & 6.82 \\
K-feldspar & 1.81 \\
Chlorite & 1.15 \\
Hematite & 0.10 \\
Pyrite & 0.60 \\
Opal-A & 0.50 \\
Rutile & 0.85 \\
\hline
\end{tabular}

Table 4. Estimated mineralogical composition of the MX-80 bentonite evaluated in this study.

Two modelling exercises were proposed based on this initial arrangement. Starting with an initial condition containing bentonite in equilibrium with the saline groundwater, the in-diffusion of dilute carbonate-rich water and brine water were simulated (water 
specifications in Table 2). Both types of water are also used as reference bounding waters in the safety assessments for the KBS-3H and KBS-3V design concepts (Hellä et al., 2014). The in-diffusion process from the host rock to the bentonite buffer (see Figure 2b) will result in changes in the composition of the water in both the micro- and the macroporosity, in variations in the distribution of the pore space between the two structural levels, and in the swelling pressure. The goal of this comparison exercise is to compare the predictions from both models regarding the evolution and final state of the system.

\section{DETAILED PROBLEM SPECIFICATION}

Although the $\mathrm{mC}$ model can simulate multicomponent reactive hydrogeochemical systems, two subsystems of different complexities were analysed to facilitate the comparison with the results of the Mc model. In the first system, which is referred to as the "complete system" in this study, gypsum and calcite were selected as readily soluble minerals. All other minerals, including montmorillonite, were treated as inert. The initial chemical conditions (shown in Table 5) were obtained after the equilibration of the saline reference water (see Table 2) with the soluble minerals. After saturating the porewater in the macroporosity with respect to gypsum and calcite, the $\mathrm{pH}$ dropped slightly, and ionic strength increased. The model predicted 29 vol\% of macroporosity and 17 vol\% of microporosity (thus adding to a total porosity of $46 \%$ ) based on the dry density and the rather high ionic strength. The cation occupancy was reflected by the microporosity composition, the Donnan equilibrium also predicted $0.5 \mathrm{eq} \%$ of anions in the microprosity. This system was only simulated with the $\mathrm{mC}$ model. 


\begin{tabular}{crrr}
\hline & $\begin{array}{r}\text { Initial } \\
\text { Saline } \\
\left(\mathbf{m o l} / \mathbf{m}^{\mathbf{3}}\right)\end{array}$ & $\begin{array}{r}\text { Macropore } \\
\text { equilibrated } \\
\left(\mathbf{m o l} / \mathbf{m}^{\mathbf{3}}\right)\end{array}$ & $\begin{array}{r}\text { Micropore } \\
\text { equilibrated } \\
\left(\mathbf{m o l} / \mathbf{m}^{\mathbf{3}}\right)\end{array}$ \\
\hline $\mathrm{SO}_{4}{ }^{2-}$ & 0.209 & 16.331 & 5.752 \\
$\mathrm{HCO}_{3}{ }^{-}$ & 0.664 & 0.658 & 0.869 \\
$\mathrm{Cl}^{-}$ & 181.942 & 182.628 & 26.039 \\
$\mathrm{Na}^{+}$ & 113.462 & 125.102 & 1134.393 \\
$\mathrm{~K}^{+}$ & 0.278 & 0.308 & 2.807 \\
$\mathrm{Ca}^{2+}$ & 32.243 & 41.916 & 3151.055 \\
$\mathrm{Mg}^{2+}$ & 2.536 & 3.385 & 237.508 \\
$\mathrm{Sr}^{2+}$ & 0.159 & 0.181 & 15.620 \\
$\mathrm{SiO}_{2}(\mathrm{aq})$ & 0.166 & 0.171 & 0.172 \\
$\mathrm{Mn}^{2+}$ & 0.006 & 0.007 & 0.569 \\
$\mathrm{Fe}^{3+}$ & 0.002 & 0.003 & 0.221 \\
$\mathrm{~F}^{-}$ & 0.053 & 0.053 & 0.006 \\
$\mathrm{Br}^{-}$ & 0.556 & 0.558 & 0.060 \\
$\mathrm{NH}_{3}(\mathrm{aq})$ & 0.000 & 0.000 & 0.000 \\
$\mathrm{HPO}_{4}{ }^{2-}$ & 0.000 & 0.000 & 0.000 \\
$\mathrm{~B}\left(\mathrm{OH}_{3}{ }^{2+}(\mathrm{aq})\right.$ & 0.120 & 0.123 & 0.123 \\
$\mathrm{O}_{2}(\mathrm{aq})$ & 0.000 & -0.259 & -0.083 \\
$\mathrm{H}^{+}$ & & 0.160 & -0.172 \\
$\mathrm{pH}_{\mathrm{Ionic} \mathrm{strength}}$ & 215.675 & 250.304 &
\end{tabular}

Table 5. Equilibrated saline water with the minerals in bentonite used as initial conditions for the complete system. Total concentrations of the solution components.

The second geochemical system was particularly simple, only considering the ions $\mathrm{Na}^{+}$, $\mathrm{Ca}^{2+}$, and $\mathrm{Cl}^{-}$(i.e., the " $\mathrm{Na}^{+}-\mathrm{Ca}^{2+}-\mathrm{Cl}^{-}$system"), and it was simulated with both $\mathrm{mC}$ and Mc models. The initial chemical condition of the macroporosity water of the $\mathrm{Na}^{+}-\mathrm{Ca}^{2+}-$ $\mathrm{Cl}^{-}$system was obtained by keeping the ionic strength and the $\mathrm{Na}^{+} / \mathrm{Ca}^{2+}$ ratio of the complete system constant and by ensuring electroneutrality (see Table 6). Micro- and macroporosity volumes remained constant, because the ionic strength was kept constant. Microporosity composition had to be calculated again by imposing Donnan equilibrium, thereby cation occupancy was slightly shifted (Table 6). 


\begin{tabular}{crr}
\hline & Macropore $\left(\mathbf{m o l} / \mathbf{m}^{\mathbf{3}}\right)$ & Micropore $\left(\mathbf{m o l} / \mathbf{m}^{\mathbf{3}}\right)$ \\
\hline $\mathrm{Cl}^{-}$ & 208.479 & 23.113 \\
$\mathrm{Na}^{+}$ & 124.829 & 1125.967 \\
$\mathrm{Ca}^{2+}$ & 41.825 & 3402.933 \\
Ionic strength & 250.304 & \\
\hline \multicolumn{2}{c}{ Table 6. Initial conditions for the Na+-Ca2+-Cl- system. }
\end{tabular}

To define the chemical Dirichlet boundary condition (i.e. imposing a constant concentration boundary), it was assumed that the bentonite was in contact with either "dilute carbonate-rich" or "brine" groundwater (Table 2), as summarized in Table 7. For the $\mathrm{Na}^{+}-\mathrm{Ca}^{2+}-\mathrm{Cl}^{-}$system, the values in Table 7 were obtained after using the same criteria as those considered in the definition of initial chemical conditions.

\begin{tabular}{|c|c|c|c|c|}
\hline & \multicolumn{2}{|c|}{ Complete system } & \multicolumn{2}{|c|}{ Simplified System } \\
\hline & $\begin{array}{c}\text { Dilute } \\
\text { carbonate rich } \\
\left(\mathbf{m o l} / \mathbf{m}^{3}\right)\end{array}$ & Brine $\left(\mathbf{m o l} / \mathbf{m}^{3}\right)$ & $\begin{array}{c}\text { Dilute } \\
\text { carbonate rich } \\
\left(\mathbf{m o l} / \mathbf{m}^{3}\right)\end{array}$ & Brine $\left(\mathrm{mol} / \mathrm{m}^{3}\right)$ \\
\hline $\mathrm{SO}_{4}^{2-}$ & 0.978 & 0.000 & & \\
\hline $\mathrm{HCO}_{3}^{-}$ & 4.762 & 0.200 & & \\
\hline $\mathrm{Cl}^{-}$ & 10.310 & 1214.753 & 18.611 & 1221.140 \\
\hline $\mathrm{Na}^{+}$ & 12.595 & 423.126 & 15.387 & 428.548 \\
\hline $\mathrm{K}^{+}$ & 0.238 & 0.561 & & \\
\hline $\mathrm{Ca}^{2+}$ & 1.320 & 391.282 & 1.612 & 396.296 \\
\hline $\mathrm{Mg}^{2+}$ & 0.725 & 4.521 & & \\
\hline $\mathrm{Sr}^{2+}$ & 0.006 & 1.835 & & \\
\hline $\mathrm{SiO}_{2}(\mathrm{aq})$ & 0.200 & 0.088 & & \\
\hline $\mathrm{Mn}^{2+}$ & 0.003 & 0.040 & & \\
\hline $\mathrm{Fe}^{3+}$ & 0.008 & 0.036 & & \\
\hline $\mathrm{S}^{2-}$ tot & 0.000 & 0.000 & & \\
\hline $\mathrm{F}^{-}$ & 0.033 & 0.084 & & \\
\hline $\mathrm{Br}^{-}$ & 0.018 & 4.362 & & \\
\hline $\mathrm{NH}_{3}(\mathrm{aq})$ & 0.040 & 0.002 & & \\
\hline $\mathrm{HPO}_{4}{ }^{2-}$ & 0.002 & 0.000 & & \\
\hline $\mathrm{B}(\mathrm{OH})_{3}(\mathrm{aq})$ & 0.026 & 0.083 & & \\
\hline $\mathrm{pH}$ & 7.8 & 7.8 & & \\
\hline Ionic strength & 20.22 & 1617.44 & 20.22 & 1617.44 \\
\hline
\end{tabular}

Table 7. Boundary conditions for the complete system and the $\mathrm{Na}^{+}-\mathrm{Ca}^{2+}-\mathrm{Cl}^{-}$system.

With regard to the initial hydromechanical condition, an isotropic stress of $3739 \mathrm{kPa}$ was introduced. This value corresponds to the swelling pressure calculated by Equation 2 for the initial ionic strength of $0.250 \mathrm{M}$. It was assumed that the described behaviour of 
bentonite will be similar to that of Na-montmorillonite. Thus, the parameters used for both models will be similar to those corresponding to this type of material. Because it is assumed that the bentonite buffer is already saturated and homogenized at the start of the analysis, a zero displacement at the contact with the host rock was considered.

Water flow was only simulated in the Mc model because the $\mathrm{mC}$ model does not allow for the simulation of water-pressure redistribution caused by the deformation resulting from the in-diffusion of water with a different salinity than the initial porewater salinity. However, this advective transport caused by this phenomenon is negligible compared with the diffusion and, consequently, has a minimal impact on overall solute transport Furthermore, as noted above, it was assumed that fully saturated conditions were present in all cases. A water pressure equal to the atmospheric pressure was considered as initial condition. A no flux condition at the surface of the canister and a constant liquid pressure equal to the initial pressure at the surface of the host rock were used as boundary conditions for water flow.

The appropriate parameterization of the two models is critical for comparing their results. Table 8 shows the transport parameters, Table 9 shows the mechanical parameters, and Table 10 shows the hydraulic parameters. The formulation and definition of these parameters is found in Appendixes A and B of this paper respectively. All parameter values have been previously used and justified by Navarro et al. (2015) for the MX-80 bentonite that was evaluated in this study and that corresponds with the MX 80 bentonite described by Kiviranta and Kumpulainen (2011). An initial wet density of $2000 \mathrm{~kg} / \mathrm{m}^{3}$ and a water content at full saturation of $29.2 \mathrm{wt} \%$ of dry was assumed, which implies an initial dry density of the buffer of $1548 \mathrm{~kg} / \mathrm{m}^{3}$. A cation exchange capacity (CEC) of 83.4 $\mathrm{cmol}(+) / \mathrm{kg}$ dry bentonite, an average MX-80 grain density of $2826 \mathrm{~kg} / \mathrm{m}^{3}$, and a specific 
surface area of $632 \mathrm{~m}^{2} / \mathrm{g}$ dry bentonite were also assumed in this study (Kiviranta and Kumpulainen, 2011).

\section{Component}

\begin{tabular}{|c|c|}
\hline $\mathbf{H}^{+}$ & $8.57 \times 10^{-9}$ \\
\hline $\mathrm{SO}_{4}{ }^{2-}$ & $1.06 \times 10^{-9}$ \\
\hline $\mathrm{HCO}_{3}^{-}$ & $1.18 \times 10^{-9}$ \\
\hline $\mathrm{Cl}^{-}$ & $2.03 \times 10^{-9}$ \\
\hline $\mathbf{N a}^{+}$ & $1.33 \times 10^{-9}$ \\
\hline $\mathbf{K}^{+}$ & $1.96 \times 10^{-9}$ \\
\hline $\mathbf{C a}^{2+}$ & $7.9 \times 10^{-10}$ \\
\hline $\mathbf{M g}^{2+}$ & $7.0 \times 10^{-10}$ \\
\hline $\mathbf{S r}^{2+}$ & $7.91 \times 10^{-10}$ \\
\hline $\mathrm{SiO}_{2}(\mathbf{a q})$ & $1.0 \times 10^{-9}$ \\
\hline $\mathrm{Mn}^{2+}$ & $7.12 \times 10^{-10}$ \\
\hline $\mathrm{Fe}^{3+}$ & $6.04 \times 10^{-10}$ \\
\hline $\mathbf{F}^{-}$ & $1.475 \times 10^{-9}$ \\
\hline $\mathbf{B r}^{-}$ & $2.08 \times 10^{-9}$ \\
\hline $\mathrm{NH}_{3}(\mathbf{a q})$ & $1.51 \times 10^{-9}$ \\
\hline $\mathrm{HPO}_{4}{ }^{2-}$ & $7.59 \times 10^{-10}$ \\
\hline $\mathbf{B}(\mathbf{O H})_{3}(\mathbf{a q})$ & $1.3 \times 10^{-10}$ \\
\hline Generic value for secondary species & $1.3 \times 10^{-9}$ \\
\hline $\begin{array}{l}\text { Macropore diffusion coefficient / diffusion } \\
\text { coefficient in free water }\end{array}$ & 0.1 \\
\hline $\begin{array}{l}\text { Micropore diffusion coefficient / diffusion } \\
\text { coefficient in free water }\end{array}$ & 0.01 \\
\hline
\end{tabular}

Table 8. Transport parameters. water $\left(\mathrm{m}^{2} / \mathbf{s}\right)$

Diffusion coefficient in free 


\begin{tabular}{lr} 
Parameter & Value \\
\hline$k$ & 0.1 \\
$\kappa_{\mathrm{io}}$ & 0.1 \\
$\alpha_{\mathrm{i}}\left(\mathrm{kPa}^{-1}\right)$ & 0 \\
$\kappa_{\mathrm{So}}$ & 0.05 \\
$\alpha_{\mathrm{Sp}}$ & 0 \\
$\alpha_{\mathrm{SS}}\left(\mathrm{kPa}^{-1}\right)$ & 0 \\
$p_{\mathrm{REF}}(\mathrm{kPa})$ & 10 \\
$v$ & 0.35 \\
$p_{\mathrm{C}}(\mathrm{kPa})$ & 10 \\
$\lambda(0)$ & 0.15 \\
$r$ & 0.8 \\
$\beta(\mathrm{kPa})$ & $2.0 \times 10^{-5}$ \\
$p_{\mathrm{O}}(\mathrm{kPa})$ & 23352 \\
$M$ & 1.07 \\
$e_{\mathrm{mR}}$ & 0.093 \\
$e_{\mathrm{mCMAX}}$ & 0.480 \\
$\alpha_{\mathrm{m}}\left(\mathrm{MPa}{ }^{-1}\right)$ & 0.016 \\
$l_{\mathrm{m}}$ & 0.612 \\
$\kappa_{\mathrm{m}}$ & 0.04 \\
$s_{\mathrm{mS}, \mathrm{O}}(\mathrm{MPa})$ & 40 \\
$\alpha_{\mathrm{DeM}, \mathrm{m}}$ & 498 \\
$\beta_{\mathrm{DeM}, \mathrm{m}}$ & 18.8 \\
$H(\mathrm{kPa} \cdot \mathrm{s})^{-1}$ & $1.5 \times 10^{-8}$ \\
$C$ & 0.4 \\
\hline Table 9. $\mathrm{Mechanical}$ & parameters. \\
&
\end{tabular}

Parameter Value

\begin{tabular}{lr}
\hline$\alpha\left(\mathrm{kPa}^{-1}\right)$ & $1.15 \times 10^{-4}$ \\
$m$ & 0.7335 \\
$b_{\mathrm{M}}$ & 9.521 \\
$n_{\mathrm{MO}}$ & 0.053 \\
$k_{\mathrm{MO}}\left(\mathrm{m}^{2}\right)$ & $6.558 \times 10^{-21}$ \\
\hline \multicolumn{2}{l}{ Table 10. Hydraulic parameters. }
\end{tabular}




\section{RESULTS}

The $\mathrm{Na}^{+}-\mathrm{Ca}^{2+}-\mathrm{Cl}^{-}$system was simulated with both the $\mathrm{mC}$ and $\mathrm{Mc}$ code. However, as it was mentioned, the complete system was also simulated with the $\mathrm{mC}$ model, and the results were used to evaluate the impact of the geochemical simplification described above.

To compare the results of the two codes, two types of graphs are shown: a spatial distribution of the variable of interest after 10 years from the start of contact with the dilute or brine water; and a comparison of the evolution of the variable of interest over time. Some of these variables correspond to the value of the cell/node most distant from the brine/ dilute water reservoir (i.e., the closest to the non-flux boundary condition on the canister surface), whereas the swelling pressure corresponds to the average value for the entire domain.

The first set of graphs (Figure 3) shows the spatial distribution of the concentrations of the three ions, as well as the ionic strengths of the macroporosity and of the two cations in the microporosity for the $\mathrm{Na}^{+}-\mathrm{Ca}^{2+}-\mathrm{Cl}^{-}$system 10 years after the start of the simulation. Even though the concentration profiles of the macroporosity are generally similar, the microporosity profiles are shown to be different. However, if the molar fractions in the microporosity are calculated, the distributions are more similar, although not equal (Figure 4). These discrepancies originate primarily from the different description of the volumes occupied by both porosity domains. Figure 5 shows the differences in the estimation of the distribution of the porosities between the $\mathrm{mC}$ and $\mathrm{Mc}$ models, particularly in the case of brine in-diffusion. The $\mathrm{mC}$ model predicts a large increase in microporosity during dilute infiltration. But the absolute total charge of the cations balancing the CEC stays constant (apart from a minor change in the already low $\mathrm{Cl}^{-}$ concentration calculated by the Donnan equilibrium, which also needs to be balanced by 
cations). Therefore, the cations concentrations (mol per microporosity volume) must decrease reciprocally to the microporosity.
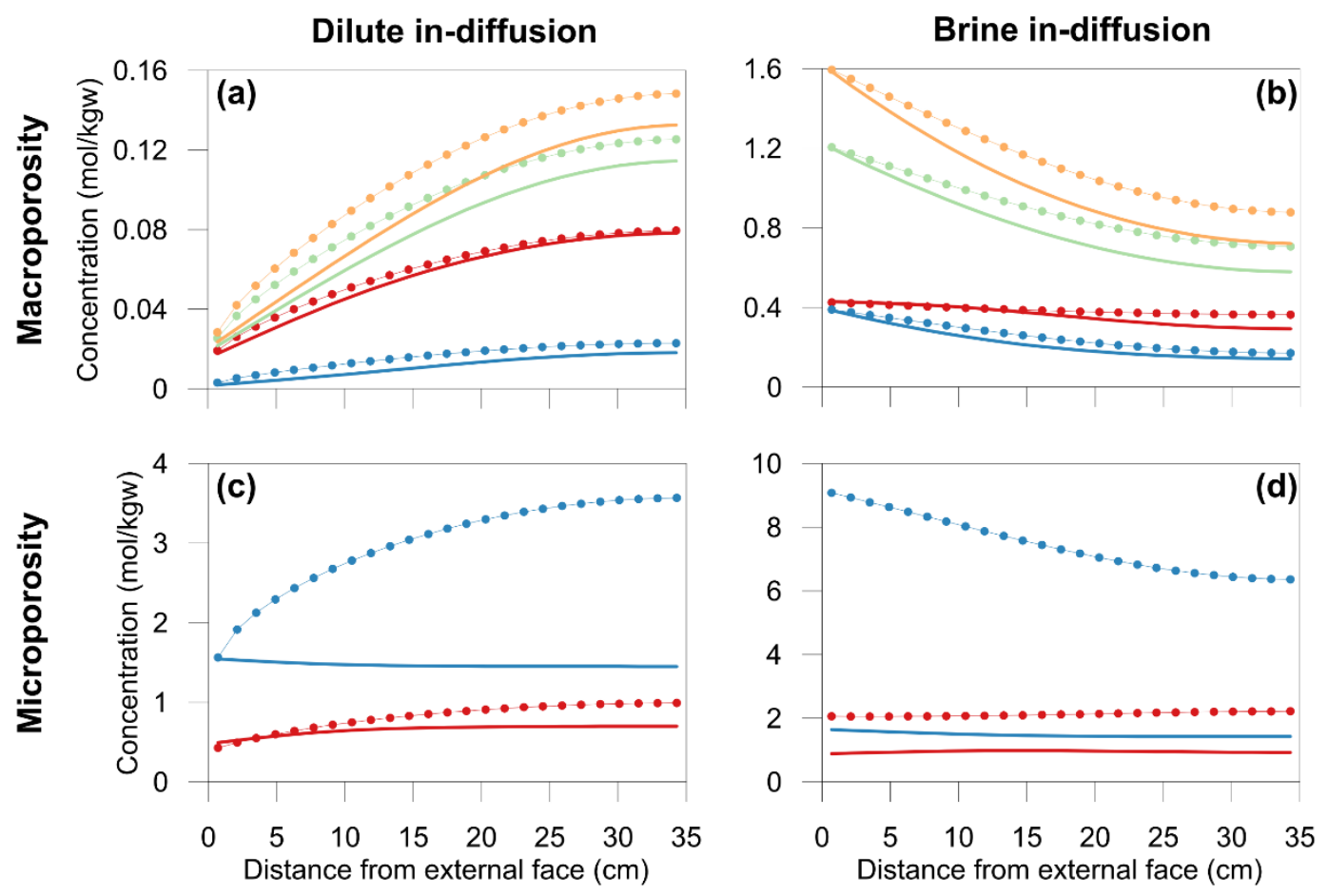

$\begin{array}{llll}-\mathrm{Na}^{+}(\mathrm{Mc})-\mathrm{Ca}^{2+}(\mathrm{Mc})-\mathrm{Cl}^{-}(\mathrm{Mc})- & \text { Ionic strength }(\mathrm{Mc}) \\ -\mathrm{Na}^{+}(\mathrm{mC})-\mathrm{Ca}^{2+}(\mathrm{mC})-\mathrm{Cl}^{-}(\mathrm{mC}) & \text { lonic strength }(\mathrm{mC})\end{array}$

Figure 3 (a) and (b) Concentration profiles of ions in the macroporosity 10 years after the start of the simulation. (c) and (d) Concentration profiles of cations in the microporosity, all results from the $\mathrm{Na}^{+}-$ $\mathrm{Ca}^{2+}-\mathrm{Cl}^{-}$system

Dilute in-diffusion

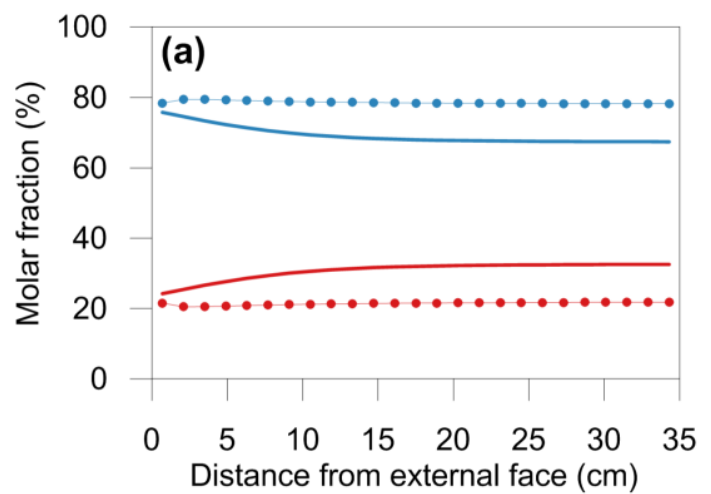

Brine in-diffusion

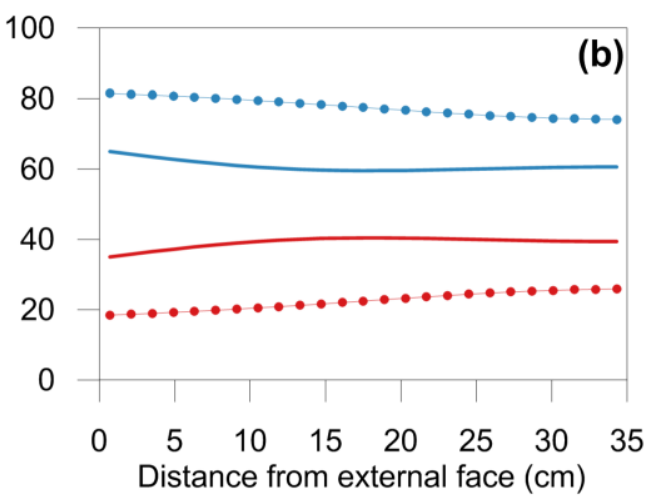

$$
-\mathrm{Na}^{+}(\mathrm{Mc}) \multimap \mathrm{Na}^{+}(\mathrm{mC})-\mathrm{Ca}^{2+}(\mathrm{Mc}) \multimap \mathrm{Ca}^{2+}(\mathrm{mC})
$$

Figure 4. Microporosity molar fraction 10 years after the start of the simulation in the $\mathrm{Na}^{+}-\mathrm{Ca}^{2+}-\mathrm{Cl}^{-}$ system (a) dilute in-diffusion (b) brine in-diffusion 


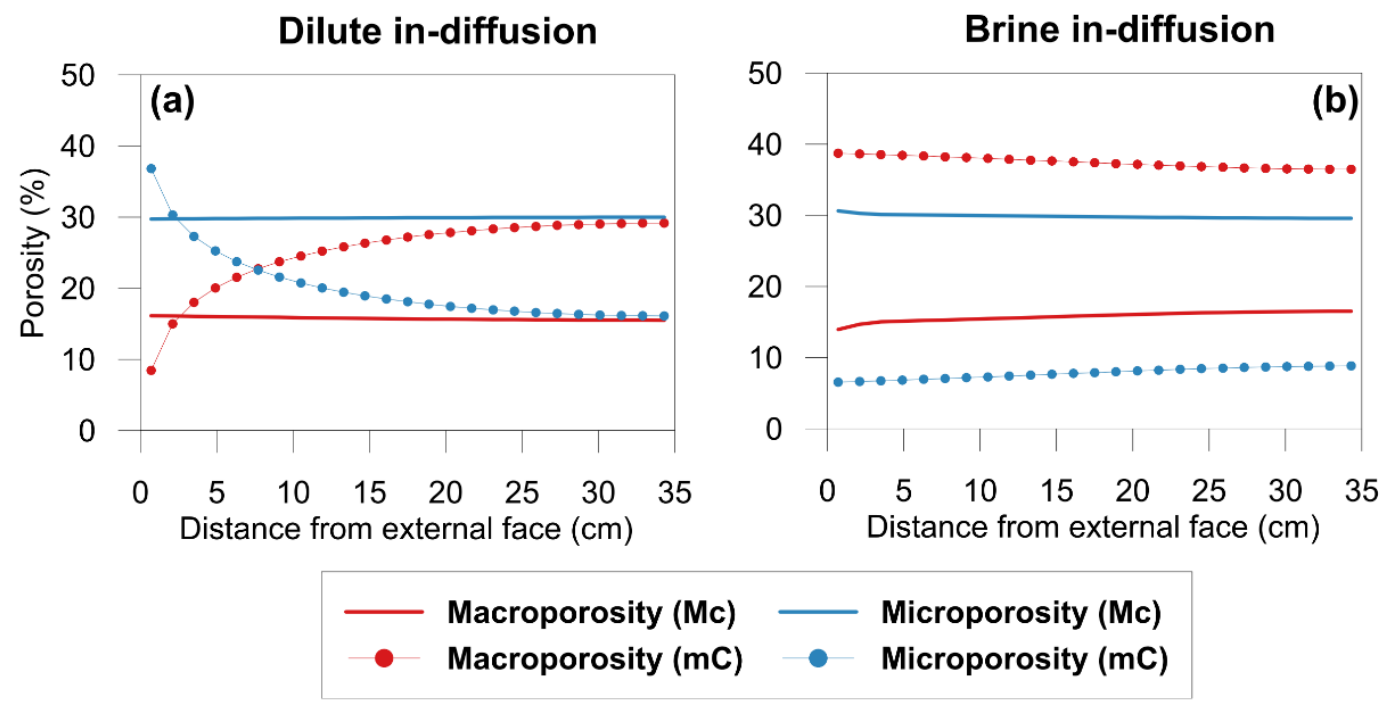

Figure 5. Distribution of porosity 10 years after the start of the simulation in the $\mathrm{Na}^{+}-\mathrm{Ca}^{2+}-\mathrm{Cl}^{-}$system (a) dilute in-diffusion (b) brine in-diffusion

In the set of comparison graphs depicting the evolution at the closest point to the canister (i.e., point "P" in Figure 2b), the concentrations in the macroporosity of the two models agree quite well (Figure 6), particularly in the case where the contacting water is the dilute water. The evolution of the molar fractions of cations in the microporosity (see Figure 7) is also shown to be similar, although there are differences that are not negligible. On the other hand, opposing evolution trends are noted in the case of contacting brine groundwater between 10 and 100 years. The differences are primarily caused by the different evolution of microstructural pore space (see Figure 8). In the mC model, microporosity variations are shown to be much faster and larger than those in the Mc model, which exhibits a stable behaviour over time. 
Dilute in-diffusion

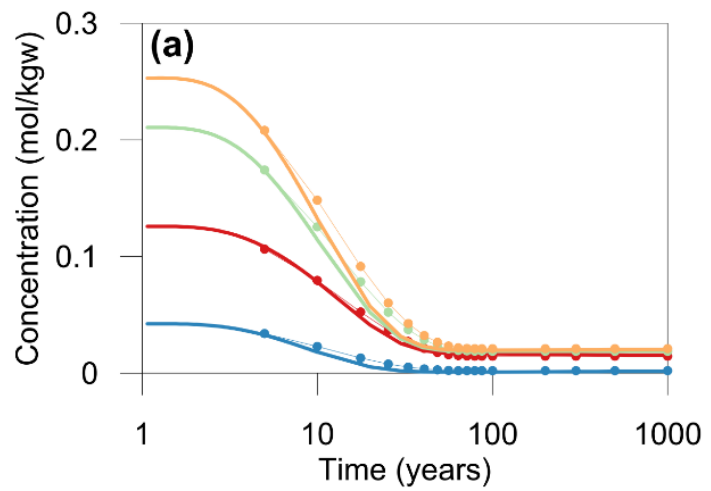

Time (years)
Brine in-diffusion

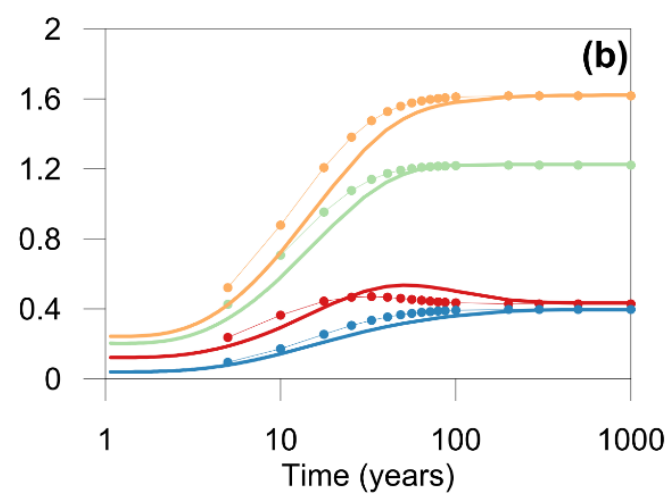

$\mathrm{Cl}^{-}(\mathrm{Mc})$

$\mathrm{Cl}^{-}(\mathrm{mC})$ lonic strength (Mc) lonic strength $(\mathrm{mC})$

Figure 6. Evolution of the macroporosity concentrations of ions of the $\mathrm{Na}^{+}-\mathrm{Ca}^{2+}-\mathrm{Cl}^{-}$system on the side closest to the canister (a) dilute in-diffusion (b) brine in-diffusion

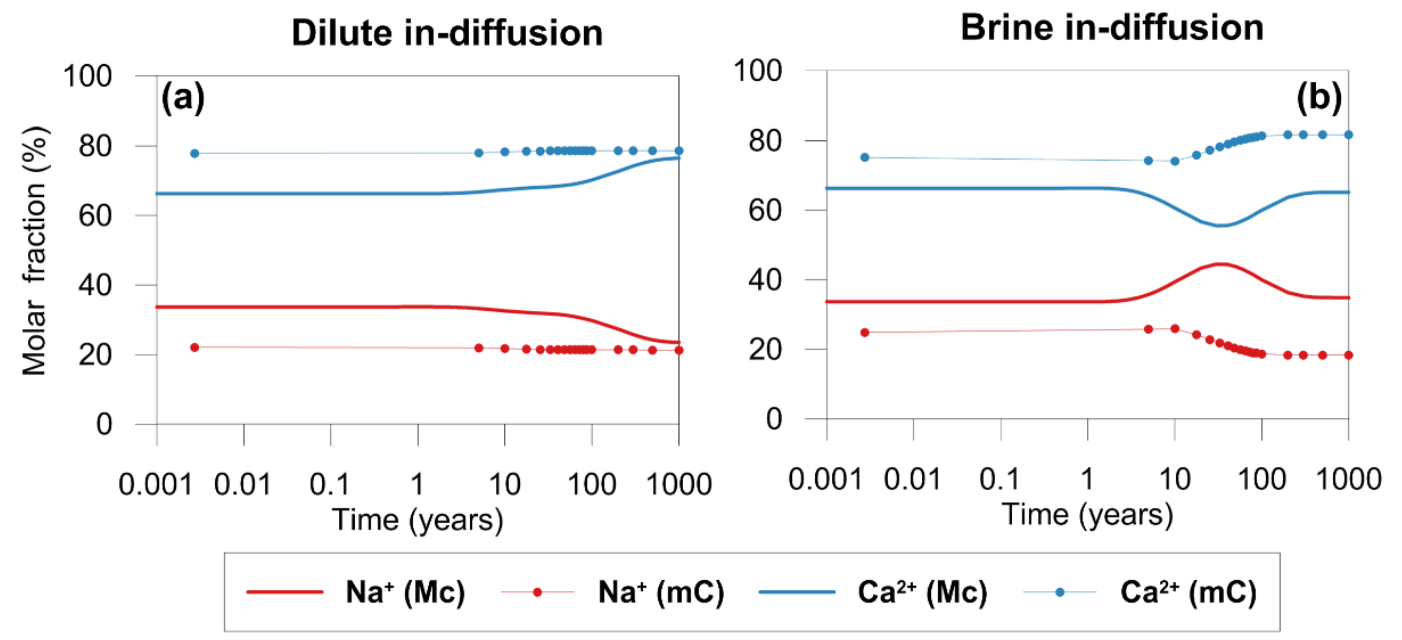

Figure 7. Evolution of the microporosity molar fraction of the cations of the $\mathrm{Na}^{+}-\mathrm{Ca}^{2+}-\mathrm{Cl}^{-}$system on the side closest to the canister (a) dilute in-diffusion (b) brine in-diffusion 


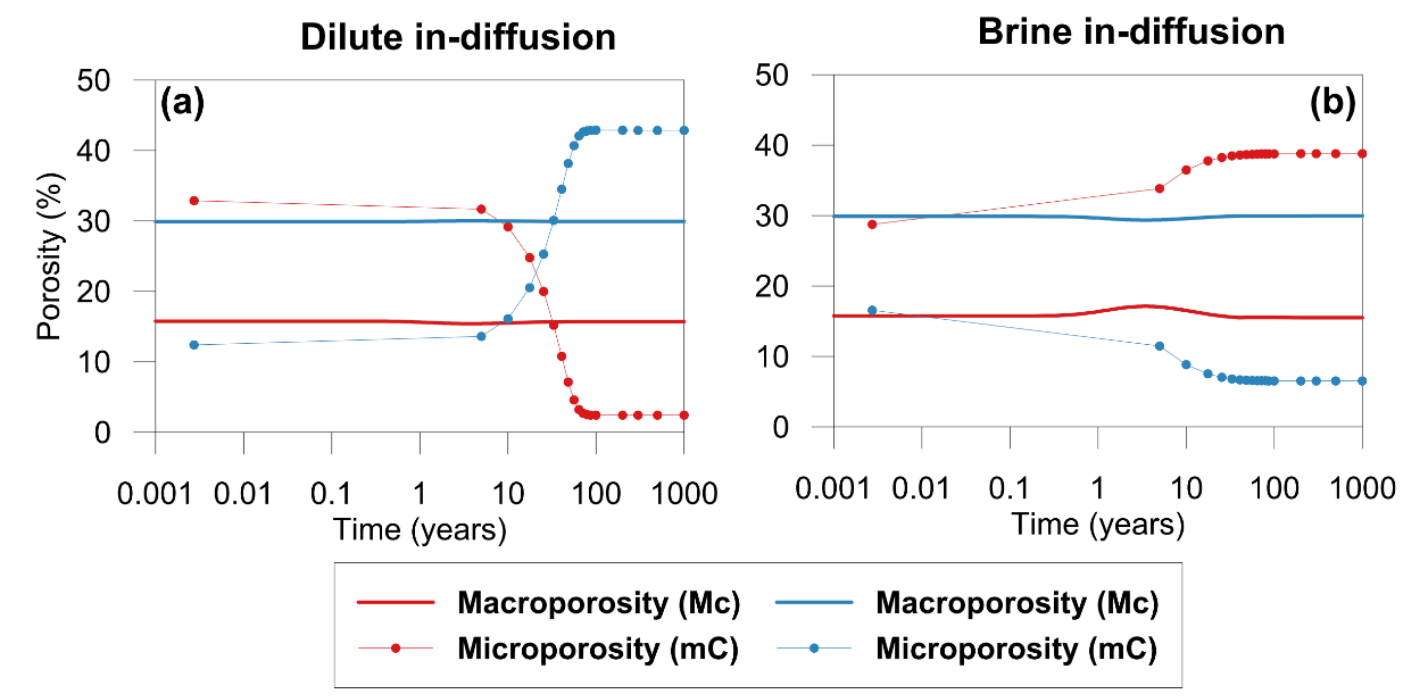

Figure 8. Evolution of the distribution of the porosities on the side closest to the canister for the Na+$\mathrm{Ca} 2+-\mathrm{Cl}-$ system (a) dilute in-diffusion (b) brine in-diffusion

Finally, considering the overall swelling pressure, both models produce similar results for both the final equilibrium value and the evolution over time, as shown in Figure 9. However, if the result of the $\mathrm{mC}$ model for the complete system is examined, the pressures predicted by both simplified models are considerably higher during the contact with dilute water. Due to the dissolution of minerals (e.g., gypsum and calcite) not included in the $\mathrm{Na}^{+}-\mathrm{Ca}^{2+}-\mathrm{Cl}^{-}$system, a major difference is shown in the ionic strengths produced by the two approaches (Figure 10). 


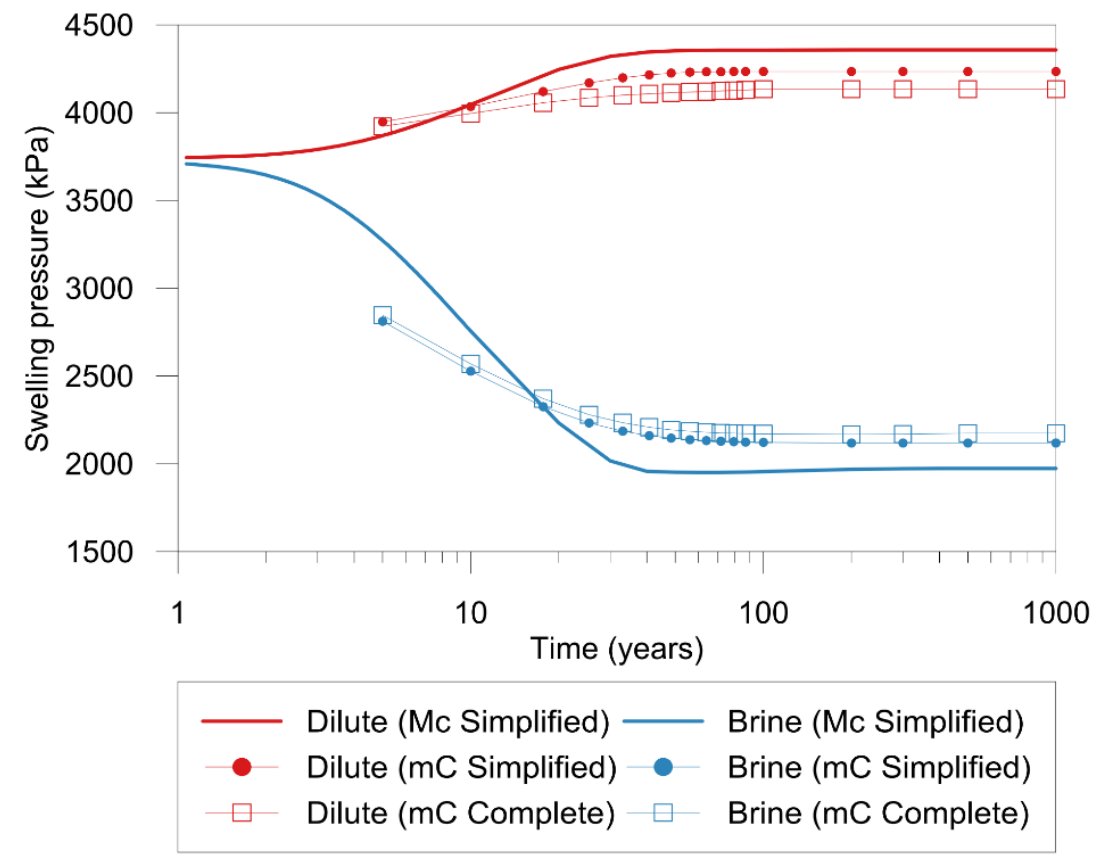

Figure 9. Evolution of the swelling pressure for the $\mathrm{Na}+-\mathrm{Ca} 2+-\mathrm{Cl}-$ system and the complete system.

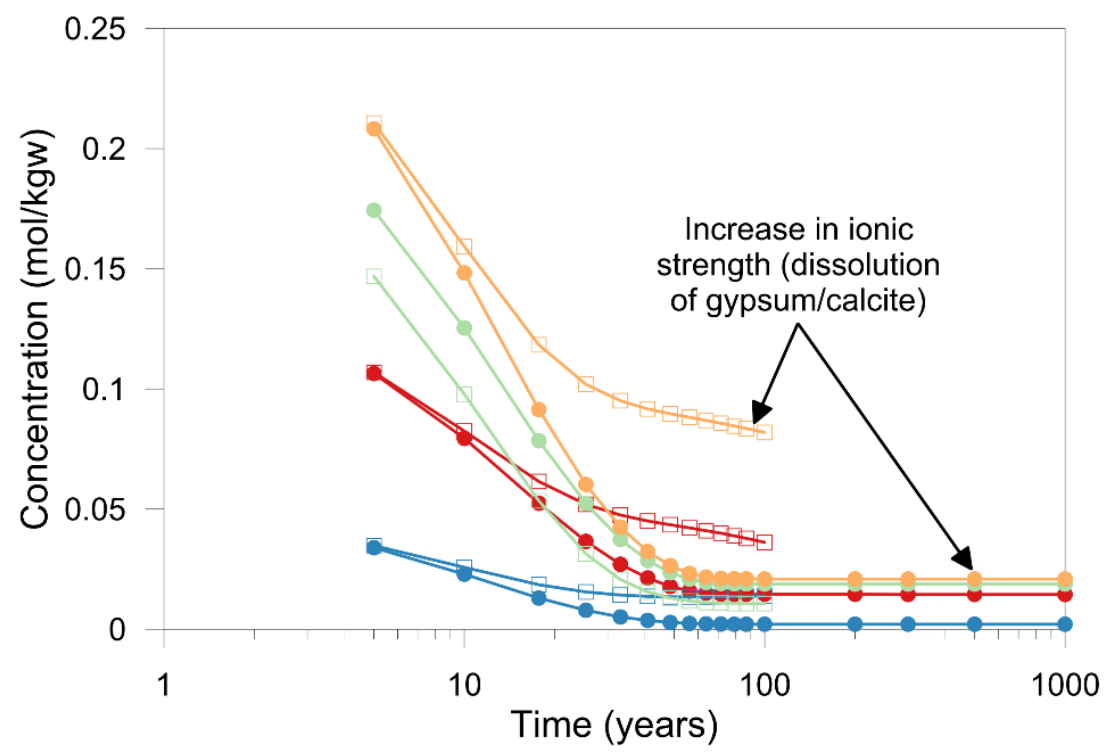
$\longrightarrow \mathrm{Na}^{+}$(mC simplified)
$\mathrm{Cl}^{-}$(mC simplified)
$\mathrm{Na}^{+}$(mC complete)
$\mathrm{Cl}^{-}$(mC complete)
$\longrightarrow \mathrm{Ca}^{2+}$ ( $\mathrm{mC}$ simplified)
lonic strength ( $\mathrm{mC}$ simplified)
$\mathrm{Ca}^{2+}$ (mC complete)
Ionic strength ( $\mathrm{mC}$ complete)

Figure 10.

Evolution of the ion concentrations in the macroporosity on the side closest to the canister for the $\mathrm{Na}^{+}-$

$\mathrm{Ca}^{2+}-\mathrm{Cl}^{-}$system and the complete system during in-diffusion of dilute groundwater (mC model). 


\section{DISCUSSION}

Despite the fundamental differences between the two models, the simulated solute concentrations in the macroporosity show good agreement. However, the response of the porosity distribution to alterations in macroporosity composition differs, resulting in differences in microporosity volume. The large differences in micro- and macroporosity fraction predicted by $\mathrm{Mc}$ and $\mathrm{mC}$ have a minor influence on solute concentration evolution (acceptable agreement in Figure 6, note the logarithmic time scale). It is on the other hand, interesting to note that the estimates of the variation of the swelling pressure due to changes in the chemical composition of the in-diffusing water are similar in the two different approaches (Figure 9). The good agreement of the Mc and $\mathrm{mC}$ swelling pressures follows from the good agreement of macroporosity ionic strengths predicted by both models, which is the main variable governing swelling pressure in $\mathrm{mC}$.

The exhaustive characterization of this material (Karnland et al., 2005; Kiviranta and Kumpulainen, 2011) allows for proposing empirical correlations between the ionic strength and swelling pressure, as presented in Equation 2. To use this equation, the simulated conditions must be similar to the test conditions described in the literature (e.g., full saturation, homogeneity of the material and full confinement), which was the case in this study. The agreement of the swelling pressures resulting from this equation (mC model) with the pressures calculated by the Mc model indicates the good performance of the Mc model. However, the mC model cannot describe the behaviour of the bentonite if it deforms. It is not possible to simulate complex processes, such as the penetration of bentonite into discontinuities of the host rock or the shear force caused by movements of the host material along the fractures (Raiko et al., 2010). It is also not possible to introduce model phenomena that include deformations and tensional changes caused by suction variations or delayed consolidation due to deformation of the microstructure. 
The swelling pressures resulting from modelling the $\mathrm{Na}^{+}-\mathrm{Ca}^{2+}-\mathrm{Cl}^{-}$system and the complete system differ markedly even under the simplified conditions used in this study. Figure 9 shows that the difference in the estimated swelling pressure is caused by the dissolution of minerals such as calcite and gypsum, which generates a large difference in the concentration of $\mathrm{Ca}^{2+}$ in the macroporosity (Figure 10). The dissolution or alteration of these or other minerals cannot be considered in a ternary system model. However, it was possible to experimentally verify (Karnland and Birgersson, 2006; Wersin et al., 2007) that these phenomena are relevant in the mechanical behaviour of a bentonite buffer. Consequently, a hydro-geomechanical model with a simplified geochemical system (Mc model) cannot reproduce the complete behavior of the bentonite under repository conditions.

This study has attempted to maintain both models within their potential fields of application while allowing them to overlap and be compared in their areas of commonality. However, even in this case, the description of the evolution of the microporosity, which includes changes in chemical and mechanical conditions, is different between the two models. In case of the $\mathrm{mC}$ model, the variation of this pore space does not include any mechanical constraint. The microporosity volume is calculated from the ionic strength, the Debye length multiplier, and other parameters assumed to be constant for the same material. This allows for large variations in the microporosity (Figure 8). Resistance from the macrostructural level to this microstructural deformation is only represented by a constant factor (Debye length multiplier). Conversely, the Mc model shows little variation in the porosity distribution over time (Figure 8). In this model, the microstructure variations lead to deformations that change the mean net stress because the system is confined; this causes the chemical potential of the microstructural water to vary (Navarro et al., 2014) and thereby alters the swelling potential of the 
aggregate. This behaviour was observed by Wang et al. (2014) for highly compacted samples of MX-80 bentonite samples saturated under constant volume conditions. Furthermore, when the tests were performed under constant load conditions and the samples were allowed to vary their volume (Musso et al., 2013), the behaviour is closer to that considered in the $\mathrm{mC}$ model. Although in both cases the referred experimental results were obtained after a decrease in matric suction, the trends of behaviour after changes in osmotic suction will probably be similar. Musso et al. (2013) carried out also the saturation process with different electrolytes with increasing concentrations showing the neutralizing effects of a decrement in matric suction and an increment in osmotic suction.

The above considerations elucidate the discrepancy of micro-/macroporosity fractions predicted by the two models, but suitable experimental data is missing to verify the predictions. Kozaki et al., (2008) found basal spacings of $1.88 \mathrm{~nm}$ in Na-montmorillonite saturated with $0-0.08 \mathrm{M} \mathrm{NaCl}$ at a dry density of $1000 \mathrm{~kg} / \mathrm{m}^{3}$ (x-ray diffraction). At $0.1 \mathrm{M}$ $\mathrm{NaCl}$, additional basal spacings were measured at $1.56 \mathrm{~nm}$, and increasingly at $0.5 \mathrm{M}$ $\mathrm{NaCl}$. Multiplication of the average montmorillonite basal spacing with the total montmorillonite surface area corresponds to microporosity volume. Therefore, these data indicates a decrease of the microporosity with increasing ionic strength saturation for such a low density. Hydraulic conductivity of bentonite is linked with the macroporosity under the assumption that advection mainly occurs in the macroporosity: higher measured conductivity then indicates higher macroporosity. This behaviour was found by Karnland et al. (2006): MX-80 bentonite showed an increasing conductivity under $\mathrm{NaCl}$ equilibration from 0.1 to $1 \mathrm{M}$, measured in the $800-1700 \mathrm{~kg} / \mathrm{m}^{3}$ dry density range. This suggests that the decrease of microporosity with increasing ionic strength measured by Kozaki et al. (2008) for $1000 \mathrm{~kg} / \mathrm{m}^{3}$ also occurs at higher densities. But especially at high 
densities, the error on the cited data increases drastically, and additional inconsistencies can be found at ionic strengths below 0.1 M. The weak data basis allows neither for verification of the model predictions, nor for further refinements of the models. More experimental data on porosity distribution at different densities at different ionic strengths is urgently needed, as well as at different cation occupancies, where the data basis is even scarcer.

Lastly, the complementary nature of both models is important because without a previous geochemical simulation that equilibrates the pore water with respect to accessory minerals, the initial chemical conditions are unrealistic. This is also true in the case where in-diffusing waters are capable of triggering dissolution/precipitation reactions. Concurrently, a prediction of the evolution of the geomechanical microporosity is unrealistic without a model that can include a mechanical variable in the chemical equilibrium. For this reason, using both models together is a useful way to evaluate swelling pressure changes resulting from chemical gradients until the chemomechanical coupling framework is fully defined.

\section{SUMMARY AND CONCLUSIONS}

This study compares the performance of two numerical codes simulating the behaviour of the bentonite buffer of an engineered barrier system exposed to different groundwaters. The models investigated in this study are based on different conceptual approaches: one is primarily a reactive transport code, and the other is intended to model the hydromechanical behaviour of bentonites. However, both models attempt to approximate the results of each other. The first model uses an empirical formulation of the swelling pressure, and the second model uses a simulation of a simplified geochemical system. 
Both models are already innovative on their own: at present, reactive transport models couple porosity only with mineral precipitation/dissolution, and mechanical models neglect the impact of porewater composition on mechanical parameters. Furthermore, only few models exist which consider the influence of charged clay mineral layer surfaces on the porewater composition and transport therein. The current approaches have to be seen as first intermediate step towards a fully coupled THM-C model (thermo-hydromechano-chemical model).

Similar results were obtained for the distribution of the concentration of ions in the macroporosity and for swelling pressure variations in a problem within the scope of both models (i.e., a $\mathrm{Na}^{+}-\mathrm{Ca}^{2+}-\mathrm{Cl}^{-}$system). However, when comparing the $\mathrm{mC}$ model results of the $\mathrm{Na}^{+}-\mathrm{Ca}^{2+}-\mathrm{Cl}^{-}$with the complete system, the differences arising from the omission of the dissolution/precipitation reactions of minerals were more apparent. The mC model on the other hand has very limited capabilities to describe the geomechanical behaviour of the bentonite since it does not solve the mechanical equilibrium equations.

However, this study shows the importance of integrating these two types of models to simulate these phenomena with greater precision, which includes the evolution of the behaviour of engineered barrier systems over time. It has also been possible to verify that a good experimental characterization of bentonite is essential even for simple models. The incomplete understanding of the physical-chemical phenomena that occur in this material can be circumvented by the use of empirical relationships to estimate its swelling pressure.

This study has shown that the connection between reactive transport models and geomechanical models in bentonite, such as MX-80, must include a correct description of the behaviour of this material at the microstructural level. Although this point has already been discussed by other authors (Guimarães et al., 2013), its importance becomes 
more apparent when comparing the results of two different conceptual approaches. In all cases, the microporosity will control both the total amount of each ion in the total porosity, overall solute transport, and the geomechanical behaviour of the system. It is therefore essential to understand how this part of the pore space evolves over time, including the physicochemical phenomena of such an evolution. Until a solid understanding of these topics is reached to define the framework of the chemomechanical coupling via the microporosity behaviour, the use of both models in a complementary manner is an interesting tool for the design evaluation of engineered barrier systems.

\section{ACKNOWLEDGEMENTS}

This work was supported by Posiva Oy, Finland. Carl Steefel is acknowledged for the clay-specific implementations in his code and for fruitful discussions.

\section{APPENDIX A. DESCRIPITION OF THE Mc MODEL}

The description of the mechanical approach of the Mc presented in this work is based on the formulations of Hoffmann et al. (2007) and Alonso et al. (2011) for the behaviour of the macrostructural level. The conceptual approach for the behaviour of the microstructure and its influence on the macrostructure, has been taken from different works on expansive clays in free swelling conditions (Navarro et al., 2014; Navarro et al., 2015a; Navarro et al., 2016) and that include salinity effects on the microstructural behaviour (Navarro et al., 2017). This appendix only summarises the formulation considered in the Mc model.

An associated plasticity approach based on the Barcelona Basic Model is used. Given the von Mises stress $q$, the slope of the critical state line $M$ (a material parameter), the net 
mean stress $p$, and the net mean yield stress at the current suction $p_{\mathrm{O}}$, the yield function F is defined as:

(A.1) $F=q^{2}-M^{2}\left(p+p_{\mathrm{S}}\right)\left(p_{\mathrm{O}}-p\right)=0$

where the increase in tensile strength with suction $p_{\mathrm{S}}$ was calculated using the expression:

(A.2) $p_{\mathrm{s}}=k \cdot s_{\mathrm{M}}$

$k$ being a material parameter and $s_{\mathrm{M}}$ being the macrostructural suction. The value of the net mean yield stress at the current suction $p_{\mathrm{O}}$ was calculated using the expression:

(A.3) $p_{\mathrm{O}}=p_{\mathrm{C}}\left(\frac{p_{\mathrm{O}} *}{p_{\mathrm{C}}}\right)^{\frac{\lambda(0)-\kappa\left(s_{\mathrm{M}}\right)}{\lambda\left(s_{\mathrm{M}}\right)-\kappa\left(s_{\mathrm{M}}\right)}}$

where the reference stress $p_{\mathrm{C}}$ is a material parameter, and the evolution of the saturated pre-consolidation stress $p_{\mathrm{O}}{ }^{*}$ is calculated from the macrostructural plastic strain rate using the hardening law:

(A.4) $d p_{\mathrm{O}} *=\frac{(1+e) p_{\mathrm{O}}^{*}}{\lambda(0)-\kappa\left(s_{\mathrm{M}}\right)} d \varepsilon_{\mathrm{MV}}{ }^{\mathrm{p}}$

In these equations, $\lambda\left(s_{\mathrm{M}}\right)$ is the slope of the virgin compression curve at macrostructural suction $s_{\mathrm{M}}$, and $\kappa\left(s_{\mathrm{M}}\right)$ is the elastic stiffness for changes in the net mean stress. To determine both magnitudes, the expressions used are:

(A.5) $\lambda\left(s_{\mathrm{M}}\right)=\lambda(0)\left[r+(1-r) \exp \left(-\beta \cdot s_{\mathrm{M}}\right)\right]$

(A.6) $\kappa\left(s_{\mathrm{M}}\right)=\kappa_{\mathrm{io}} \cdot\left(1+\alpha_{\mathrm{i}} \cdot s_{\mathrm{M}}\right)$

where $\lambda(0), r, \beta, \kappa_{\mathrm{io}}$ and $\alpha_{\mathrm{i}}$ are material parameters.

The macrostructural elastic volumetric strain $d \varepsilon_{\mathrm{MV}}{ }^{\mathrm{e}}$ was obtained using the expression:

(A.7) $d \varepsilon_{\mathrm{MV}}{ }^{\mathrm{e}}=\frac{d p}{K_{\mathrm{p}}}+\frac{d s_{\mathrm{M}}}{K_{\mathrm{s}}}$

where the "basic" value of the "stress" bulk modulus $K_{\mathrm{p}}$ was obtained using the expression: 
(A.8) $K_{\mathrm{p}}=\frac{p(1+e)}{\kappa\left(s_{\mathrm{M}}\right)}$

and the "suction" bulk modulus $K_{\mathrm{s}}$ was obtained with the expression:

(A.9) $K_{\mathrm{s}}=\frac{\left(s_{\mathrm{M}}+P_{\mathrm{ATM}}\right)(1+e)}{\kappa_{\mathrm{S}}\left(s_{\mathrm{M}}, p\right)}$

Here, $\kappa_{\mathrm{S}}\left(s_{\mathrm{M}}, p\right)$ is the elastic stiffness for changes in suction, which was calculated as follows:

$(\mathrm{A} .10) \kappa_{\mathrm{S}}\left(s_{\mathrm{M}}, p\right)=\kappa_{\mathrm{So}} \cdot\left[1+\alpha_{\mathrm{Sp}} \cdot \operatorname{Ln}\left(\frac{p}{p_{\mathrm{REF}}}\right)\right] \cdot \exp \left(\alpha_{\mathrm{SS}} \cdot s_{\mathrm{M}}\right)$

where $\kappa_{\mathrm{So}}, \alpha_{\mathrm{Sp}}, p_{\mathrm{REF}}$ and $\alpha_{\mathrm{SS}}$ are material parameters.

Regarding the formulation of the conceptual model of the microstructural behaviour, the constitutive equation that links the microstructural void ratio $\left(e_{\mathrm{m}}\right)$ and the chemomechanical variables is given in the form:

(A.11) $e_{\mathrm{m}}=e_{\mathrm{mC}}+\Delta e_{\mathrm{mO}}$

where $e_{\mathrm{mC}}$ is the microstructural void ratio associated with crystalline swelling y $\Delta e_{\mathrm{mO}}$ is the increment of the microstructural void ratio caused by the osmotic swelling. Both terms are calculated as follows:

(A.12) $e_{\mathrm{mC}}=e_{\mathrm{mR}}+\frac{e_{\mathrm{mCMAX}}}{\left(1+\left(\alpha_{\mathrm{m}} \cdot s_{\mathrm{mS}}\right)^{1 /\left(1-l_{\mathrm{m}}\right)}\right)^{l_{\mathrm{m}}}}$

(A.13) $\Delta e_{\mathrm{mO}}=-\kappa_{\mathrm{m}} \cdot \operatorname{Ln}\left(\frac{s_{\mathrm{mS}}+P_{\mathrm{ATM}}}{s_{\mathrm{mS}, \mathrm{O}}+P_{\mathrm{ATM}}}\right)$

where $e_{\mathrm{mR}}, e_{\mathrm{mCMAX}}, \alpha_{\mathrm{m}}, l_{\mathrm{m}}, \kappa_{\mathrm{m}}$ and $s_{\mathrm{mS}, \mathrm{O}}$ are material parameters and $s_{\mathrm{mS}}$ is the matric microstructural suction. 
The kinetic term for water mass exchange between micro and macroporosity $\left(c_{\mathrm{m}}\right)$ is given by the expression:

(A.14) $\frac{c_{\mathrm{m}}}{\rho_{\mathrm{W}}}=H\left(\frac{p+s_{\mathrm{M}}-s_{\mathrm{MO}}}{s_{\mathrm{mS}}-s_{m \mathrm{O}}}\right)^{C}\left(s_{\mathrm{mS}}-s_{m \mathrm{O}}-p-s_{\mathrm{M}}+s_{\mathrm{MO}}\right)$

where $\rho_{\mathrm{w}}$ is the water density, $s_{\mathrm{M}}$ is the macrostructural matric suction $s_{\mathrm{MO}}$ is the macrostructural osmotic suction, and where $H$ and $C$ are model parameters.

The volumetric strain of the macrostructure induced by the destructuration of the microstructural level is based on the state surface defined by the expression:

(A.15) $\Delta e_{\mathrm{M}, \mathrm{m}}=\alpha \cdot\left(e_{\mathrm{m}}\right)^{\beta}$

where $\Delta e_{\mathrm{M}, \mathrm{m}}$ es the increment in the macrostructural void ratio $\left(e_{\mathrm{M}}\right)$ caused by a variation of $e_{\mathrm{m}}$ and $\alpha \mathrm{y} \beta$ are material parameters.

With regard to the water flow, a van Genuchten retention curve (van Genuchten, 1980) was used to define the variation of the macrostructural degree of saturation $\mathrm{Sr}_{\mathrm{M}}$ in relation to the macrostructural suction $s_{\mathrm{M}}$ (Navarro et al., 2015b):

(A.16) $\frac{S r_{\mathrm{M}}-S r_{\mathrm{M}, 0}}{1-S r_{\mathrm{M}, 0}}=\left[1+\left(\alpha \cdot s_{M}\right)^{n}\right]^{-m}$

where $S r_{\mathrm{M}, 0}$ is the residual degree of saturation (equal to 0 ) and where, if the relationship $n=1 /(1-m)$ is assumed, $\alpha$ and $m$ are the only two material parameters. Furthermore, the model for the intrinsic permeability $\left(K_{\mathrm{M}}\right)$ proposed by Gens et al. (2011) has been used:

(A.17) $K_{\mathrm{M}}=k_{M O} \cdot \exp \left[b_{\mathrm{M}} \cdot\left(n_{\mathrm{M}}-n_{\mathrm{M} 0}\right)\right]$

where $k_{M O}$ is the intrinsic permeability for the reference porosity $n_{\mathrm{M} 0} ; n_{\mathrm{M}}$ is the macroporosity; and $b_{\mathrm{M}}$ is a constitutive parameter. 


\section{APPENDIX B. DESCRIPTION OF VARIABLES AND FORMULATION REFERENCES}

\begin{tabular}{|c|c|c|}
\hline Parameter & Definition & Reference \\
\hline$b_{\mathrm{M}}$ & Intrinsic permeability fitting parameter & Gens (2011) \\
\hline$C$ & $\begin{array}{l}\text { Fitting coefficient for the mass transfer } \\
\text { interaction }\end{array}$ & Navarro (2014) \\
\hline$e_{\mathrm{mR}}$ & Additional microstructural void ratio & Navarro (2015) \\
\hline $\mathrm{e}_{\mathrm{mCMAX}}$ & $\begin{array}{l}\text { Microstructural void ratio associated with } \\
\text { the crystalline swelling at saturation }\end{array}$ & Navarro (2015) \\
\hline$H$ & $\begin{array}{l}\text { Transfer coefficient at the end of the mass } \\
\text { exchange process between micro and } \\
\text { macrostructural levels }\end{array}$ & Navarro (2014) \\
\hline$k$ & Increase in cohesion with suction & Alonso (2011) \\
\hline$k_{\mathrm{MO}}\left(\mathrm{m}^{2}\right)$ & Reference intrinsic permeability & Gens (2011) \\
\hline $1 \mathrm{~m}$ & Fitting parameter of $e_{\mathrm{mC}}$ & Navarro (2015) \\
\hline$M$ & Slope of the critical state line & Alonso (2011) \\
\hline$m$ & $\begin{array}{l}\text { Van Genuchten's retention curve fitting } \\
\text { parameter }\end{array}$ & Navarro (2015) \\
\hline$n_{\mathrm{MO}}$ & $\begin{array}{l}\text { Reference porosity at which the } \\
\text { macroscopic intrinsic permeability is equal } \\
\text { to } k_{\mathrm{MO}}\end{array}$ & Gens (2011) \\
\hline$p_{\mathrm{C}}$ & Reference stress & Alonso (2011) \\
\hline$p_{\mathrm{O}}{ }^{*}$ & Saturated pre-consolidation stress & Alonso (2011) \\
\hline$p_{\text {REF }}$ & Material parameter used to define $\kappa_{\mathrm{s}}$ & Alonso (2011) \\
\hline$r$ & $\begin{array}{l}\text { Material parameter used to define the } \\
\text { macrostructural soil compressibility }\end{array}$ & Alonso (2011) \\
\hline$s_{\mathrm{mS}, \mathrm{O}}$ & $\begin{array}{l}\text { Microstructural suction at which osmotic } \\
\text { swelling begins to play a significant role }\end{array}$ & Navarro (2015) \\
\hline$\alpha$ & $\begin{array}{l}\text { Van Genuchten's retention curve fitting } \\
\text { parameter }\end{array}$ & Navarro (2015) \\
\hline$\alpha_{\mathrm{DeM}, \mathrm{m}}$ & $\begin{array}{l}\text { Fitting parameter of the surface state that } \\
\text { defines the micro and macrostructural } \\
\text { interaction }\end{array}$ & Navarro (2016) \\
\hline
\end{tabular}




\begin{tabular}{|c|c|c|}
\hline Parameter & Definition & Reference \\
\hline$\alpha_{\mathrm{i}}$ & $\begin{array}{l}\text { Material parameter of the elastic stiffness } \\
\text { for changes in the net mean stress }\end{array}$ & Hoffmann (2007) \\
\hline$\alpha_{\mathrm{m}}$ & Fitting parameter of $e_{\mathrm{mC}}$ & Navarro (2015) \\
\hline$\alpha_{\mathrm{Sp}}$ & $\begin{array}{l}\text { Material parameter used to define } \kappa_{\mathrm{S}} \text {. } \\
\text { Dimensionless }\end{array}$ & Alonso (2011) \\
\hline$\alpha_{\mathrm{SS}}$ & Material parameter used to define $\kappa_{S}$. & Alonso (2011) \\
\hline$\beta$ & $\begin{array}{l}\text { Material parameter used to define the } \\
\text { macrostructural soil compressibility }\end{array}$ & Alonso (2011) \\
\hline$\beta_{\mathrm{DeM}, \mathrm{m}}$ & $\begin{array}{l}\text { Fitting parameter of the surface state that } \\
\text { defines the micro and macrostructural } \\
\text { interaction }\end{array}$ & Navarro (2016) \\
\hline$\kappa_{\text {io }}$ & $\begin{array}{l}\text { Material parameter of the elastic stiffness } \\
\text { for changes in the net mean stress }\end{array}$ & Hoffmann (2007) \\
\hline$\kappa_{\mathrm{m}}$ & Microstructural stiffness parameter & Navarro (2015) \\
\hline$\kappa_{\text {So }}$ & $\begin{array}{l}\text { Material parameter of the elastic stiffness } \\
\text { for changes in suction }\end{array}$ & Alonso (2011) \\
\hline$\kappa_{S}(s, p)$ & $\begin{array}{l}\text { Elastic stiffness for changes in suction } \\
\text { evaluated at macrostructural suction s and } \\
\text { net mean stress p. }\end{array}$ & Alonso (2011) \\
\hline$\lambda(0)$ & $\begin{array}{l}\text { Slope of the virgin compression curve for } \\
\text { saturated conditions }\end{array}$ & Alonso (2011) \\
\hline$v$ & Poisson's ratio & Alonso (2011) \\
\hline
\end{tabular}




\section{REFERENCES}

Alonso, E.E., Alcoverro, J., Coste, F., Malinsky, L., Merrien-Soukatchoff, V., Kadiri, I., Nowak, T., Shao, H., Nguyen, T.S., Selvadurai, A.P.S., Armand, G., Sobolik, S.R., Itamura, M., Stone, C.M., Webb, S.W., Rejeb, A., Tijani, M., Maouche, Z., Kobayashi, A., Kurikami, H., Ito, A., Sugita, Y., Chijimatsu, M., Börgesson, L., Hernelind, J., Rutqvist, J., Tsang, C.F., Jussila, P., 2005. The FEBEX benchmark test: Case definition and comparison of modelling approaches. Int. J. Rock Mech. Min. Sci. 42, 611-638. http://dx.doi.org/10.1016/j.ijrmms.2005.03.004

Alonso, E.E., Gens, A., Josa, A., 1990. A constitutive model for partially saturated soils. Geotechnique 40, 405-430. http://dx.doi.org/10.1680/geot.1990.40.3.405

Alonso, E.E., Romero, E., Hoffmann, C., 2011. Hydromechanical behaviour of compacted granular expansive mixtures: experimental and constitutive study. Geotechnique 61, 329-344. http://dx.doi.org/10.1680/geot.2011.61.4.329

Alonso, E.E., Vaunat, J., Gens, A., 1999. Modelling the mechanical behaviour of expansive clays. Eng. Geol. 54, 173-183. http://dx.doi.org/10.1016/S00137952(99)00079-4

Alt-Epping, P., Tournassat, C., Rasouli, P., Steefel, C.I., Mayer, K.U., Jenni, A., Mäder, U., Sengor, S.S., Fernández, R., 2015. Benchmark reactive transport simulations of a column experiment in compacted bentonite with multispecies diffusion and explicit treatment of electrostatic effects. Comput. Geosci. 19, 535-550. http://dx.doi.org/10.1007/s10596-014-9451-x

Arthur, R., Apted, M., Stenhouse, M., 2005. Comment on the Long-Term Chemical and Mineralogical Stability of the Buffer, SKI Report 2005: 09, Swedish Nuclear Power Inspectorate, Stockholm, Sweden.

Arthur, R.C., Zhou, W., 2000. Chemical Buffering in Natural and Engineered Barrier Systems: Thermodynamic Constraints and Performance Assessment Consequences., SKI Report 01:11, Swedish Nuclear Power Inspectorate, Stockholm, Sweden.

Birgersson, M., Börgesson, L., Hedström, M., Karnland, O., Nilsson, U., 2009. Bentonite erosion. Final report, TR-09-34, Swedish Nuclear Fuel and Waste Management Co (SKB), Stockholm, Sweden, p. 172.

Bolt, G.H., 1956. Physico-chemical analysis of the compressibility of pure clays. Geotechnique 6, 86-93. http://dx.doi.org/10.1680/geot.1956.6.2.86

Börgesson, L., Johannesson, L.E., Sanden, T., Hernelind, J., 1995. Modelling of the physical behaviour of water saturated clay barriers Laboratory tests, material models and finite element application, TR-95-20, Swedish Nuclear Fuel and Waste Management Co (SKB), Stockholm,Sweden, p. 150.

Börgesson, L., Karnland, O., Johannesson, L.E., 1996. Modelling of the physical behaviour of clay barriers close to water saturation. Eng. Geol. 41, 127-144. http://dx.doi.org/10.1016/0013-7952(95)00030-5

Calvello, M., Lasco, M., Vassallo, R., Di Maio, C., 2005. Compressibility and residual shear strength of smectitic clays: Influence of pore aqueous solutions and organic solvents. Riv. Ital. Geotec. 1, 34-46. 
Castellanos, E., Gens, A., Lloret, A., Romero, E., 2006. Influence of water chemistry on the swelling capacity of a high-density bentonite, Geotech SP 147 ed, pp. 962-972. http://dx.doi.org/10.1061/40802(189)77\#sthash.35U5dRwj.dpuf

Castellanos, E., Villar, M.V., Romero, E., Lloret, A., Gens, A., 2008. Chemical impact on the hydro-mechanical behaviour of high-density FEBEX bentonite. Phys. Chem. Earth 33, Supplement 1, S516-S526. http://dx.doi.org/10.1016/j.pce.2008.10.056

Chen, Y.-G., Zhu, C.-M., Ye, W.-M., Cui, Y.-J., Chen, B., 2016. Effects of solution concentration and vertical stress on the swelling behavior of compacted GMZ01 bentonite. Appl. Clay Sci. 124-125, 11-20. http://dx.doi.org/10.1016/j.clay.2016.01.050

Cho, W.-J., Lee, J.-O., Kang, C.-H., 2002. Influence of Salinity on The Hydraulic Conductivity of Compacted Bentonite. MRS Proc. 713. https://doi.org/10.1557/PROC$\underline{713-J J 11.50}$

Di Maio, C., 1996. Exposure of bentonite to salt solution: Osmotic and mechanical effects. Geotechnique 46, 695-707. http://dx.doi.org/10.1680/geot.1996.46.4.695

Di Maio, C., Fenelli, G.B., 1994. Residual strength of kaolin and bentonite: the influence of their constituent pore fluid. Geotechnique 44, 217-226. http://dx.doi.org/10.1680/geot.1994.44.2.217

Di Maio, C., Santoli, L., Schiavone, P., 2004. Volume change behaviour of clays: The influence of mineral composition, pore fluid composition and stress state. Mech. Mater. 36, 435-451. http://dx.doi.org/10.1016/S0167-6636(03)00070-X

Dixon, D.A., 2000. Porewater salinity and the development of swelling pressure in bentonite-based buffer and backfill materials, Posiva 2000-04, Posiva Oy, Helsinki, Finland.

Dixon, D.A., Gray, M.N., Graham, J., 1996. Swelling and Hydraulic Properties of Bentonites from Japan, Canada and the USA, in: Kamon, M. (Ed.), Environmental Geotechnics. Balkema, Rotterdam, pp. 43-48.

Gens, A., Alonso, E.E., 1992. A framework for the behaviour of unsaturated expansive clays. Can. Geotech. J. 29, 1013-1032. http://dx.doi.org/10.1139/t92-120

Gens, A., Valleján, B., Sánchez, M., Imbert, C., Villar, M.V., van Geet, M., 2011. Hydromechanical behaviour of a heterogeneous compacted soil: Experimental observations and modelling. Geotechnique 61, 367-386. http://dx.doi.org/10.1680/geot.SIP11.P.015

Gómez-Espina, R., Villar, M.V., 2010. Geochemical and mineralogical changes in compacted MX-80 bentonite submitted to heat and water gradients. Appl. Clay Sci. 47, 400-408. http://dx.doi.org/10.1016/j.clay.2009.12.004

Gómez-Espina, R., Villar, M.V., 2015. Effects of heat and humidity gradients on MX-80 bentonite geochemistry and mineralogy. Appl. Clay Sci. 109-110, 39-48. http://dx.doi.org/10.1016/j.clay.2015.03.012

Guimarães, L.D.N., Gens, A., Sánchez, M., Olivella, S., 2013. A chemo-mechanical constitutive model accounting for cation exchange in expansive clays. Geotechnique 63, 221-234. http://dx.doi.org/10.1680/geot.SIP13.P.012

Hellä, P., Pitkänen, P., Löfman, J., Partamies, Wersin, P., Vuorinen, U., 2014. Safety Case for the Disposal of Spent Nuclear Fuel at Olkiluoto - Definition of Reference and 
Bounding Groundwaters, Buffer and Backfill Porewaters, POSIVA 2014-04, Posiva Oy, Olkiluoto, Finland, p. 164.

Herbert, H.J., Kasbohm, J., Moog, H.C., Henning, K.H., 2004. Long-term behaviour of the Wyoming bentonite MX-80 in high saline solutions. Appl. Clay Sci. 26, 275-291. http://dx.doi.org/10.1016/j.clay.2003.12.028

Herbert, H.J., Kasbohm, J., Sprenger, H., Fernández, A.M., Reichelt, C., 2008. Swelling pressures of MX-80 bentonite in solutions of different ionic strength. Phys. Chem. Earth 33, S327-S342. http://dx.doi.org/10.1016/j.clay.2003.12.028

Hökmark, H., Karnland, O., Pusch, R., 1997. A technique for modeling transport/conversion processes applied to smectite-to-illite conversion in HLW buffers. Eng. Geol. 47, 367-378. http://dx.doi.org/10.1016/S0013-7952(96)00120-2

Holmboe, M., Wold, S., Jonsson, M., 2012. Porosity investigation of compacted bentonite using XRD profile modeling. J. Contam. Hydrol. 128, 19-32. http://dx.doi.org/10.1016/j.jconhyd.2011.10.005

Hoffmann, C., Alonso, E.E., Romero, E., 2007. Hydro-mechanical behaviour of bentonite pellet mixtures. Phys. Chem. Earth 32, 832-849. http://dx.doi.org/10.1016/j.pce.2006.04.037

Jeong, S.W., Locat, J., Leroueil, S., 2012. The effects of salinity and shear history on the rheological characteristics of illite-rich and Na-montmorillonite-rich clays. Clay Clay Miner. 60, 108-120. http://dx.doi.org/10.1346/CCMN.2012.0600202

Karnland, O., 1998. Bentonite swelling pressure in strong $\mathrm{NaCl}$ solutions Correlation of model calculations to experimentally determined data, POSIVA 98-01, Posiva Oy, Olkiluoto, Finland, p. 34.

Karnland, O., Birgersson, M., 2006. Montmorillonite Stability with Special Respect to KBS-3 Conditions, Montmorillonite Stability with Special Respect to KBS-3 Conditions, TR-06-11, Swedish Nuclear Fuel and Waste Management Co (SKB), Stockholm,Sweden, p. 38.

Karnland, O., Muurinen, A., Karlsson, F., 2005. Bentonite swelling pressure in $\mathrm{NaCl}$ solutions - Experimentally determined data and model calculations, in Alonso, E.E., Ledesma, A. (Eds), Advances in Understanding Engineered Clay Barriers - Proceedings of the International Symposium on Large Scale Field Tests in Granite, Taylor and Francis, London, pp. 241-256.

Karnland, O., Olsson, S., Nilsson, U., 2006. Mineralogy and sealing properties of various bentonites and smectite-rich clay materials, TR-06-30, Swedish Nuclear Fuel and Waste Management Co (SKB), Stockholm,Sweden, p. 112.

Karnland, O., Sanden, T., Johannesson, L.-E., Eriksen, T.E., Jansson, M., Wold, S., Pedersen, K., Motamedi, M., Rosborg, B., 2000. Long term test of buffer material Final Report on the pilot parcels, TR-00-22, Swedish Nuclear Fuel and Waste Management Co (SKB), Stockholm,Sweden, p. 154.

Kiviranta, L., Kumpulainen, S., 2011. Quality control and characterization of bentonite materials, Working Report 2011-84, Posiva Oy, Olkiluoto, Finland, p. 102.

Kozaki, T., Liu, J., Sato, S., 2008. Diffusion mechanism of sodium ions in compacted montmorillonite under different $\mathrm{NaCl}$ concentration. Phys. Chem. Earth 33, 957-961. http://dx.doi.org/10.1016/j.pce.2008.05.007 
Lei, X., Wong, H., Fabbri, A., Limam, A., Cheng, Y.M., 2014. A thermo-chemo-electromechanical framework of unsaturated expansive clays. Comput. Geotech. 62, 175-192. http://dx.doi.org/10.1016/j.compgeo.2014.07.004

Li, X., Chen, G., Verstricht, J., Van Marcke, P., Troullinos, I., 2013. The large scale insitu PRACLAY heater and seal tests in URL HADES, Mol, Belgium, in Proceedings of the International Conference on Radioactive Waste Management and Environmental Remediation, ICEM. http://dx.doi.org/doi:10.1115/ICEM2013-96294

Liu, J.-F., Skoczylas, F., Talandier, J., Pu, H., 2016. Dismantling of the EB experiment: Experimental research on the retrieved GBM and bentonite blocks. Nucl. Eng. Des. 300, 297-307. http://dx.doi.org/10.1016/j.nucengdes.2016.01.023

Low, P.F., 1980. The swelling of clay: II. Montmorillonites. Soil Sci. Soc. Am. J. 44, 667-676. http://dx.doi.org/10.2136/sssaj1980.03615995004400040001x

Martín, P.L., Barcala, J.M., Villar, M.V., 2014. Behaviour of a bentonite barrier under thermal and hydraulic gradients: FEBEX mock-up test, 16 years of operation, in Khalili, N., Russell, A., Khoshghalb, A. (Eds), Unsaturated Soils: Research and Applications Proceedings of the 6th International Conference on Unsaturated Soils, UNSAT 2014, CRC Press/Balkema, Leiden, The Netherlands, pp. 857-862.

Marty, N.C.M., Fritz, B., Clément, A., Michau, N., 2010. Modelling the long term alteration of the engineered bentonite barrier in an underground radioactive waste repository. Appl. Clay Sci. 47, 82-90. http://dx.doi.org/10.1016/j.clay.2008.10.002

Mesri, G., Olson, R.E., 1971. Consolidation characteristics of montmorillonite. Geotechnique 21, 341-352. http://dx.doi.org/10.1680/geot.1971.21.4.341

Musso, G., Romero, E., della Vecchia, G., 2013. Double-structure effects on the chemohydro-mechanical behaviour of a compacted active clay. Geotechnique 63, 206-220. http://dx.doi.org/10.1680/geot.SIP13.P.011

Navarro, V., Alonso, E.E., 2000. Modeling swelling soils for disposal barriers. Comput. Geotech. 27, 19-43. http://dx.doi.org/10.1016/S0266-352X(00)00002-1

Navarro, V., Asensio, L., De la Morena, G., Pintado, X., Yustres, A., 2015. Differentiated intra- and inter-aggregate water content models of mx-80 bentonite. Appl. Clay Sci. 118, 325-336. http://dx.doi.org/10.1016/j.clay.2015.10.015

Navarro, V., Asensio, L., Yustres, A., De la Morena, G., Pintado, X., 2016. Swelling and mechanical erosion of MX-80 bentonite: Pinhole test simulation. Eng. Geol. 202, 99-113. http://dx.doi.org/10.1016/j.enggeo.2016.01.005

Navarro, V., Asensio, L., Yustres, A., Pintado, X., Alonso, J., 2013. Volumetric deformability and water mass exchange of bentonite aggregates. Eng. Geol. 166, 152159. http://dx.doi.org/10.1016/j.enggeo.2013.09.011

Navarro, V., Asensio, L., Yustres, A., Pintado, X., Alonso, J., 2014. An elastoplastic model of bentonite free swelling. Eng. Geol. 181, 190-201. http://dx.doi.org/10.1016/j.enggeo.2014.07.014

Navarro, V., Yustres, Á., Asensio, L., De la Morena, G., Laurila, T., Pintado, X., 2017. Modelling of compacted bentonite swelling that accounts for salinity effects. Submitted to Engineering Geology. 
Nykyri, M., Nordman, H., Loefman, J., Poteri, A., Marcos, N., Hautojorvi, A., 2008. Radionuclide release and transport RNT-2008, POSIVA 2008-06, Posiva Oy, Olkiluoto, Finland, p. 164.

Olivella, S., Gens, A., Carrera, J., Alonso, E.E., 1996. Numerical formulation for a simulator (CODE_BRIGHT) for the coupled analysis of saline media. Eng. Computation. 13, 87-112. http://dx.doi.org/10.1108/02644409610151575

Pacovský, J., Svoboda, J., Zapletal, L., 2007. Saturation development in the bentonite barrier of the Mock-Up-CZ geotechnical experiment. Phys. Chem. Earth 32, 767-779. http://dx.doi.org/10.1016/j.pce.2006.03.005

Posiva Oy, 2012. Safety Case for the Disposal of Spent Nuclear Fuel at Olkiluoto Design Basis 2012. POSIVA 2012-03, Posiva Oy, Olkiluoto, Finland, p. 177.

Posiva Oy, 2013. KBS-3H Complementary Studies, 2008-2010, POSIVA 2013-03 Posiva Oy, Olkiluoto, Finland, p. 322.

Pusch, R., 1980. Swelling pressure of highly compacted bentonite. TR-80-13, Swedish Nuclear Fuel and Waste Management Co (SKB), Stockholm, p. 35.

Raiko, H., Sandström, R., Rydén, H., Johansson, M., 2010. Design analysis report for the canister. TR-10-28, Swedish Nuclear Fuel and Waste Management Co (SKB), Stockholm, p. 79.

Romero, E., Della Vecchia, G., Jommi, C., 2011. An insight into the water retention properties of compacted clayey soils. Geotechnique 61, 313-328. http://dx.doi.org/10.1680/geot.2011.61.4.313

Sánchez, M., Gens, A., do Nascimento Guimarães, L., Olivella, S., 2005. A double structure generalized plasticity model for expansive materials. Int. J. Numer. Anal. Met. 29, 751-787. http://dx.doi.org/10.1002/nag.434

Savage, D., 2005. The effects of high salinity groundwater on the performance of clay barriers, SKI Report 2005: 54, Swedish Nuclear Power Inspectorate, Stockholm, Sweden. Sweden, p. 46.

Sedighi, M., Thomas, H.R., Vardon, P.J., 2015. Reactive transport of chemicals in unsaturated soils: numerical model development and verification. Can. Geotech. J. 53, 162-172. http://dx.doi.org/10.1139/cgj-2014-0436

Sinnathamby, G., Korkiala-Tanttu, L., Salvador, L.T., 2015. Shear resistance of bentonite backfill materials and their interfaces under varying hydraulic conditions in a deep rock nuclear waste repository. Appl. Clay Sci. 104, 211-220. http://dx.doi.org/10.1016/j.clay.2014.11.035

SKB, 2010. Buffer, backfill and closure process report for the safety assessment SR-Site. TR-10-47, Swedish Nuclear Fuel and Waste Management Co (SKB), Stockholm, p. 360.

Smith, P., Neall, F., Snellman, M., Pastina, B., Nordman, H., Johnson, L., Hjerpe, T., 2008. Safety assessment for a KBS-3H spent nuclear fuel repository at Olkiluoto Summary report, POSIVA 2007-06, Posiva Oy, Olkiluoto, Finland, p. 199.

Sridharan, A., Rao, G.V., 1973. Mechanisms controlling volume change of saturated clays and the role of the effective stress concept. Geotechnique 23, 359-382. http://dx.doi.org/10.1680/geot.1973.23.3.359

Steefel, C.I., Appelo, C.A.J., Arora, B., Jacques, D., Kalbacher, T., Kolditz, O., Lagneau, V., Lichtner, P.C., Mayer, K.U., Meeussen, J.C.L., Molins, S., Moulton, D., Shao, H., 
Šimůnek, J., Spycher, N., Yabusaki, S.B., Yeh, G.T., 2015. Reactive transport codes for subsurface environmental simulation. Computat. Geosci. 19, 445-478. http://dx.doi.org/10.1007/s10596-014-9443-x

Svoboda, J., 2007. The Mock-up-CZ experiment, in Sarsby, R.W., Felton, A.J. (Eds.), Geotechnical and Environmental Aspects of Waste Disposal Sites - Proceedings of Green4 International Symposium on Geotechnics Related to the Environment, Taylor \& Francis, London, pp. 81-90.

Thomas, H.R., He, Y., 1997. A coupled heat-moisture transfer theory for deformable unsaturated soil and its algorithmic implementation. Int. J. Numer. Meth. Eng. 40, http://dx.doi.org/ NME220>3.0.CO;2-C 10.1002/(SICI)1097-0207(19970930)40:18<3421::AID-

Tournassat, C., Appelo, C.A.J., 2011. Modelling approaches for anion-exclusion in compacted Na-bentonite. Geochim. Cosmochim. Ac. 75, 3698-3710. http://dx.doi.org/10.1016/j.gca.2011.04.001

van Genuchten, M.T., 1980. A Closed-form Equation for Predicting the Hydraulic Conductivity of Unsaturated Soils. Soil Sci. Soc. Am. J. 44, 892-898. http://dx.doi.org/892-898. 10.2136/sssaj1980.03615995004400050002x

Wang, Q., Cui, Y.-J., Minh Tang, A., Xiang-Ling, L., Wei-Min, Y., 2014. Time- and density-dependent microstructure features of compacted bentonite. Soils Found. 54, 657666. http://dx.doi.org/10.1016/j.sandf.2014.06.021

Wersin, P., Johnson, L.H., McKinley, I.G., 2007. Performance of the bentonite barrier at temperatures beyond $100{ }^{\circ} \mathrm{C}$ : A critical review. Phys. Chem. Earth 32, 780-788. http://dx.doi.org/10.1016/j.pce.2006.02.051

Xiaodong, L., Prikryl, R., Pusch, R., 2011. THMC-testing of three expandable clays of potential use in HLW repositories. Appl. Clay Sci. 52, 419-427. http://dx.doi.org/10.1016/j.clay.2011.03.021

Yamaguchi, T., Sakamoto, Y., Akai, M., Takazawa, M., Iida, Y., Tanaka, T., Nakayama, S., 2007. Experimental and modeling study on long-term alteration of compacted bentonite with alkaline groundwater. Phys. Chem. Earth 32, 298-310. http://dx.doi.org/10.1016/j.pce.2005.10.003

Ye, W.M., Zhang, F., Chen, B., Chen, Y.G., Wang, Q., Cui, Y.J., 2014. Effects of salt solutions on the hydro-mechanical behavior of compacted GMZ01 Bentonite. Environ. Earth Sci. 72, 2621-2630. http://dx.doi.org/10.1007/s12665-014-3169-X

Ye, W.M., Zhu, C.M., Chen, Y.G., Chen, B., Cui, Y.J., Wang, J., 2015. Influence of salt solutions on the swelling behavior of the compacted GMZ01 bentonite. Environ. Earth Sci. 74, 793-802. http://dx.doi.org/10.1007/s12665-015-4108-1

Zhu, C.-M., Ye, W.-M., Chen, Y.-G., Chen, B., Cui, Y.-J., 2013. Influence of salt solutions on the swelling pressure and hydraulic conductivity of compacted GMZ01 bentonite. Eng. Geol. 166, 74-80. http://dx.doi.org/10.1016/j.enggeo.2013.09.001

Zhu, C.M., Ye, W.M., Chen, Y.G., Chen, B., Cui, Y.J., 2015. Impact of cyclically infiltration of $\mathrm{CaCl} 2$ solution and de-ionized water on volume change behavior of compacted GMZ01 bentonite. Eng. Geol. 184, 104-110. http://dx.doi.org/10.1016/j.enggeo.2014.11.005 